Portland State University

PDXScholar

2-11-1993

\title{
An Analysis of the Involvement of Ten High Schools in Scholastic Aptitude Testing Student Preparation
}

\author{
Elaine Drakulich \\ Portland State University
}

Follow this and additional works at: https://pdxscholar.library.pdx.edu/open_access_etds

Part of the Education Commons

Let us know how access to this document benefits you.

\section{Recommended Citation}

Drakulich, Elaine, "An Analysis of the Involvement of Ten High Schools in Scholastic Aptitude Testing Student Preparation" (1993). Dissertations and Theses. Paper 1154.

https://doi.org/10.15760/etd.1153

This Dissertation is brought to you for free and open access. It has been accepted for inclusion in Dissertations and Theses by an authorized administrator of PDXScholar. Please contact us if we can make this document more accessible: pdxscholar@pdx.edu. 


\begin{abstract}
AN ANALYSIS OF THE INVOLVEMENT OF TEN HIGH SCHOOLS IN SCHOLASTIC APTITUDE TESTING

STUDENT PREPARATION

by

ELAINE DRAKULICH

A dissertation submitted in partial fulfillment of the requirements for the degree of

\author{
DOCTOR OF EDUCATION \\ in \\ EDUCATIONAL LEADERSHTP: \\ ADMINISTRATION AND SUPERVISION
}

Portland State University

1993 
TO THE OFFICE OF GRADUATE STUDIES:

The members of the committee approve the dissertation of Elaine Drakulich presented February 11, 1993.

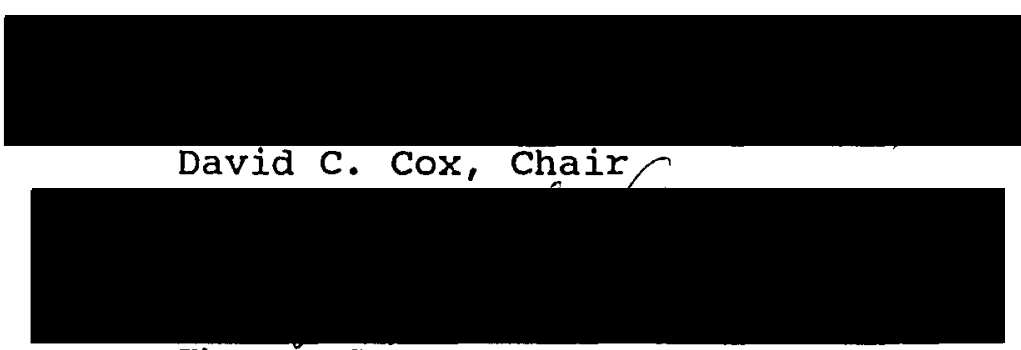

Thomas G. Greene

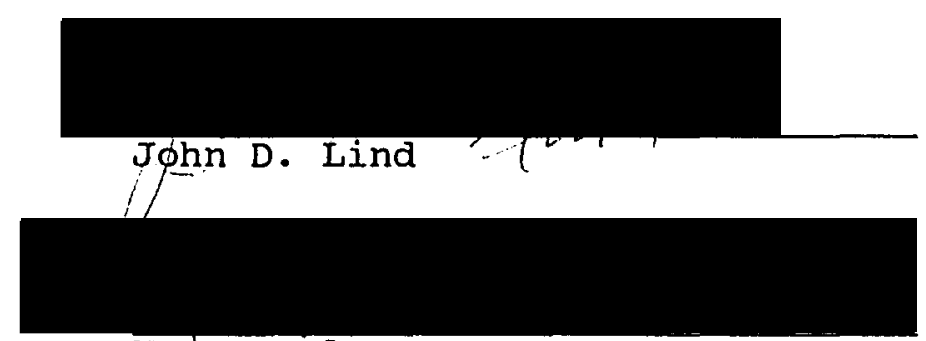

M. Carrol Tama

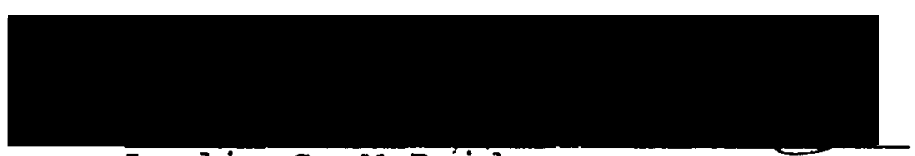

Leslie G. McBride

APPROVED :

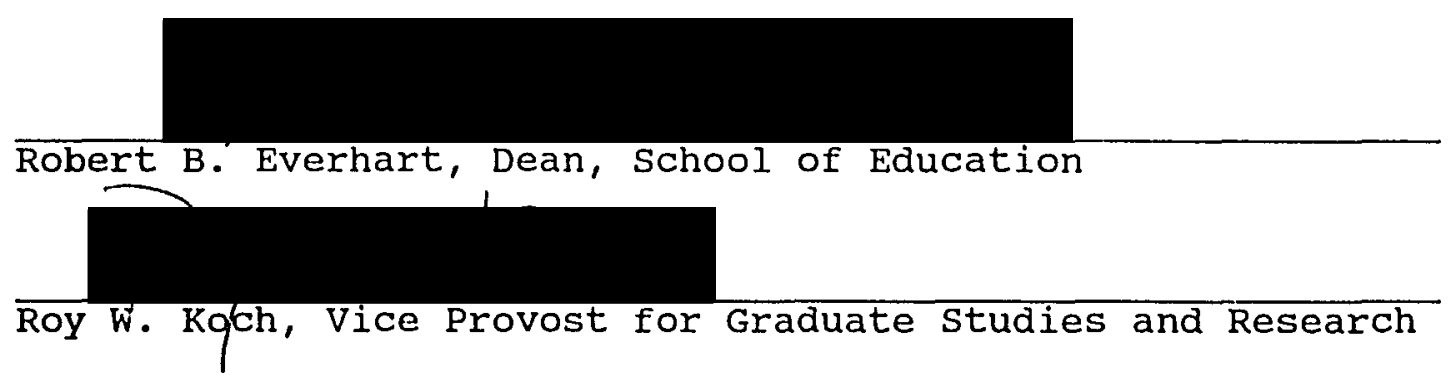


AN ABSTRACT OF THE DISSERTATION OF Elaine Drakulich for the Doctor of Education in Educational Leadership:

Administration and Supervision presented February 11, 1993.

Title: An Analysis of the Involvement of Ten High Schools in Scholastic Aptitude Testing student Preparation

APPROVED BY THE MEMBERS OF THE DISSERTATION COMMTTTEE:

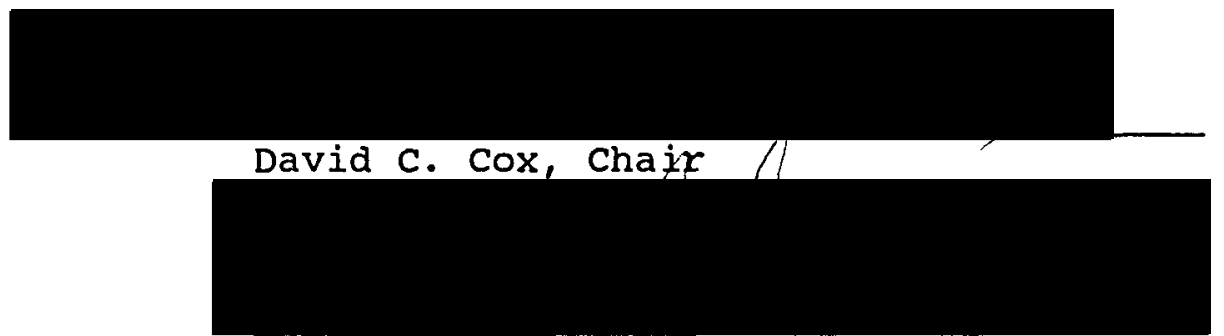

Thomas G. Greene
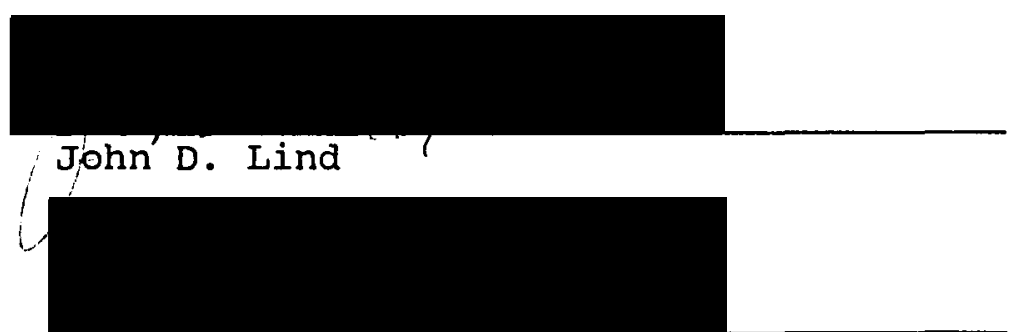

M. Carrol Tama

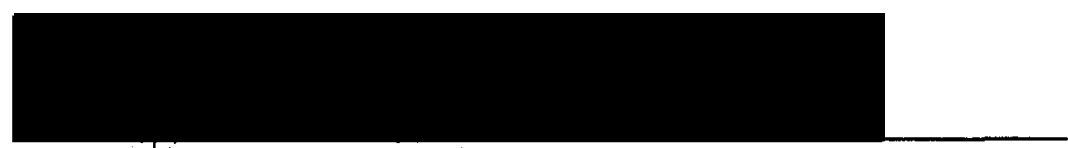

Léslie G. McBride

The Scholastic Aptitude Test (SAT) is taken each year by two fifths of the high school graduates (Cameron, 1989). The perception that high SAT scores will either open the door of selective colleges and generate scholarships or 
that low SAT scores will close off opportunities for the rest of one's life, makes virtually every student who invests the three hours of time required to take the test extremely anxious about doing as well as possible (Whitla, 1988). Significant relationships between identified preparation techniques and the perceived effectiveness of those techniques by students and staff can be very useful information for educators when counseling and/or assisting students who want to improve their performance on the SAT. This study describes perceptual opinions from students, teachers, counselors, and administrators from 10 Portland, oregon metropolitan area schools about the effectiveness of three SAT preparation techniques.

The following research questions were examined:

1. What is the perceived effectiveness of three SAT preparation techniques: SAT computer programs, SAT preparation classes, and specific SAT information taught in general classes?

2. Are students who regard the SAT as important more likely to know about, use, and perceive effective the three preparation techniques than students who do not?

3. Are students who regard the SAT as important more likely to perceive their teachers or administrators as valuing the SAT than students who do not?

4. Are students who perceive that their teachers or administrators regard the SAT as important more likely to 
perceive the preparation techniques effective than students who do not?

The results of this study indicated some specific groups of students and teachers did perceive one preparation technique to be effective. Their perceptions validated belief in specific SAT information taught in general classes as an effective preparation technique.

It also revealed that there was lack of awareness, use, and perceived effectiveness of both SAT computer programs and SAT preparation classes.

Lastly, the study showed that both students and teachers who perceived the SAT to be important, agreed that their administrators valued the SAT. 


\section{ACKNOWLEDGEMENTS}

The author wishes to gratefully acknowledge the contributions of the following persons whose inspiration, support, and assistance made this dissertation possible.

For serving on my dissertation committee: David c. Cox (Chair), Thomas G. Greene, John D. Lind, M. Carrol Tama, and Leslie G. MCBride.

For providing technical expertise: Lee Chapman, Ron Dexter, Donna Kirk, and Doug Salyers.

Finally, my children and husband for their endless support and love: Nicholas David Drakulich, Scott Vincent Drakulich, Corrin Nicole Drakulich, and Nicholas Alan Drakulich. 
TABLE OF CONTENTS

PAGE

ACKNOWLEDGEMENTS. . . . . . . . . . . . . . . . . iii IIST OF TABLES. . . . . . . . . . . . . . . . . . vii LIST OF FIGURES . . . . . . . . . . . . . . . . . viii CHAPTER

$\mathrm{I}$

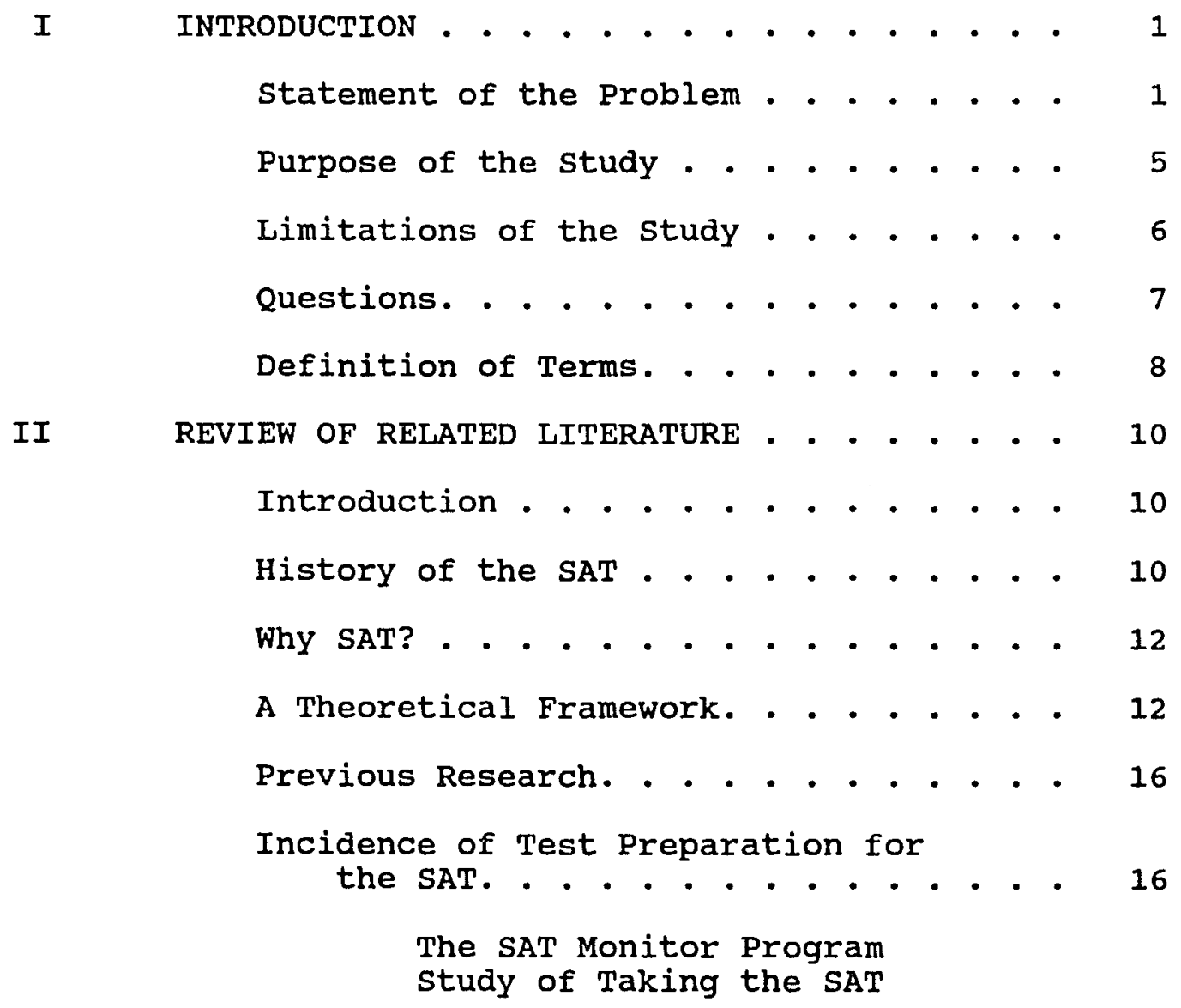


School-Sponsored Preparation for the

Survey of Secondary Schools Preparation Intervention

Commercial Preparation Techniques. . . 20

study of SAT Microcomputer Coaching

Survey of Commercial SAT

Coaching

All Special Test Preparation . . . . . 22

Preparing for the SAT: A

Survey of Programs and

Resources

Summary. • . . . • . . . . . . 25

III DESIGN OF THE RESEARCH - . . . . . . . . . 27

Sample Design. . . . . . . . . . 27

Development of the Questionnaire . . . 28

Description of the Scholastic Aptitude Preparation Survey . . . . . . 29

Collection of the Data . . . . . . . 31

Data Analysis. . . . . . . . . . 32

IV PRESENTATION AND ANALYSIS OF DATA. . . . . 35

Introduction . . . . . . . . . 35

Statistical Analysis . . . . . . . 36

$$
\begin{aligned}
& \text { Question I } \\
& \text { Question II } \\
& \text { Question III } \\
& \text { Question IV }
\end{aligned}
$$


Conclusions. . . . . . . . . . . 68

Question I

Question II

Question III

Question IV

Recommendations for Future Research. . . 75

REFERENCES. . . . . . . . . . . . . . . . . 78

APPENDICES

A THE SCHOLASTIC APTITUDE PREPARATION SURVEYS. - 86

B TEST PREPARATION SUPPORTING DATA . . . . . . 96 


\section{LIST OF TABLES}

I Scholastic Aptitude SAT Score Averages . . . 14

II Number of Questionnaire Respondents. . . . 28

III Are students who Value the SAT More Likely to Use the Preparation Techniques Than Those who Do Not Value the SAT? . . . . . . . . . . 58

IV Do Teachers, students, or Counselors/ Administrators Who Value the SAT for students Perceive that SAT Computer Programs, SAT Prep Classes, or Specific SAT Information Taught in General Classes is More Effective Than Those Who Do Not Value the SAT? . 


\section{LIST OF FIGURES}

FIGURE

PAGE

1. Student Perceived Effectiveness of Three SAT Preparation Techniques . .

2 .

Teacher Perceived Effectiveness of Three SAT Preparation Techniques . . 38

3 .

Counselor/Administrator Perceived Effectiveness of Three SAT Preparation Techniques . . . . . .

4 .

Did Students Who Were Enrolled in College Prep/Advanced Classes Perceive the Preparation Techniques Differently Than Those who Were Not Enrolled?. . . . . . . . . . .

5.

Did Students Who Had Taken or Planned to Take the SAT Perceive the Preparation Techniques Differently Than Those Who Had Not?. . . . .

Did Students Who Planned to Attend a Four Year College Perceive the Preparation Techniques Differently Than Those Who Had Not?. . . . .

7.

'Perceptions of the Availability of SAT Computer Preparation Programs . . . . . . . . . . 50

8. Perceptions of the Use of SAT Computer Preparation Programs . . . . . . .

Perceptions of the Availability of SAT Preparation Classes. . . . . .

10 .

Perceptions of the Use of SAT Preparation Classes. . . . . . .

11.

Methods Which Teachers Use to Provide Specific SAT Information in classes . . . . . . 
12 .

Higher Level Thinking Skills Methods Which Teachers Use to Provide Specific SAT Information in classes. . . . . . . . . . .

13.

Are Students Who Regard the SAT as Important More Likely to Perceive Their Teachers or Administrators as Valuing the SAT?. . . . . . . .

14.

Do Teachers Perceive Their Administrators Value the SAT and Do the Teachers Themselves Value the SAT? . . . . . . . . .

15.

Are Counselors/Administrators Who Regard the SAT as Important More Likely to Perceive Themselves or Their Teachers as Valuing the SAT? . . . . . . . . . . . . . 
CHAPTER I

INTRODUCTION

STATEMENT OF THE PROBLEM

According to Cameron (1989), Executive Director of Research and Development at the college Board, the Scholastic Aptitude Test (SAT) is probably known to more Americans than any other examination except the one taken to qualify for a driver's license. The SAT is taken each year by two fifths of the high school graduates as a rite of passage from secondary school to higher education.

The SAT is a useful tool for teachers and counselors for giving guidance to high school students. It can be used to assist students in choosing college majors and thinking about careers. It can help students in selecting colleges where they are likely to find the academic competition congenial, and in scaling up or down students' and parents' expectations of the college to which students plan to apply (Cameron, 1989).

The perception that SAT scores will either open the door of selective colleges and generate scholarships or close off opportunities for the rest of one's life, makes virtually every student who invests the three hours of time required to take the test extremely anxious about doing as 
required to take the test extremely anxious about doing as well as possible and getting a good score (Whitla, 1988). More than $90 \%$ of those admitted to Princeton University, Smith College, Stanford University, Wellesley College, Brown University, University of Chicago, and the Massachusetts Institute of Technology scored over 550 on both the SAT verbal and mathematical tests (College Entrance Exam Board [CEEB], 1989c). In addition, Harvard University and Radcliffe College admit only $15 \%$ of their applicants with the 50th percentile of their students scoring between 620 and 720 on their SAT verbal (SAT-V) scores and between 650 and 750 on their SAT mathematics (SAT-M) scores. Yale admits $18 \%$ of its applicants, and its middle 50th percentile scores for SAT-V are 610-710 and for SAT-M are 650-740. The University of California Berkeley accepts $31 \%$ of its applicants and the middle 50th percentile of its students score between 480-630 on the SAT-V and 560 and 720 on the SAT-M. The University of Notre Dame admits $45 \%$ of its applicants who have middle 50th percentile scores of SAT-V (530-630) and SAT-M (590-700). While most of America's 2,135 four year colleges admit the majority of their applicants, schools such as Stanford University, admitted 17 out of every 100 applicants last year (CEEB, 1989C). This type of competition has induced parents, students, and educators to seek preparation techniques to improve students' success on the SAT, and therefore students' 
chances of admission and scholarships to select colleges and universities.

Today, despite the fact that SATs have been disparaged by consumer advocates, minority groups, and educators, approximately one million students take the test annually (Crouse, 1986a). Powers (1988) concludes that so far no one has demonstrated that preparation is sufficiently effective for all students to recommend spending significant amounts of time or money on it. Cameron (1989) states that students can accomplish at least as much in school or on their own. However, Cameron (1989) also states that because Scholastic Aptitude Tests measure what has been learned, they are not impervious to the effects of instruction including self-efficacy. Bandura's (1986) theoretical model of self-efficacy is used throughout this study to support test preparation through taught self-efficacy. Bandura defines self-efficacy as demonstration of strong self-beliefs that ensure optimal use of learning and skills of knowledge. If self-efficacy is lacking, students tend to demonstrate knowledge ineffectually, even though they know the information. Self-efficacy in this study applies to students' optimal use of learning during testing.

Cameron's (1989) beliefs in the effects of instruction and Bandura's (1986) theory of taught self-efficacy support the demand for special preparation for the SAT. The demand for special preparation for Scholastic Aptitude Tests, 
whether conducted as a part of the school curriculum, as an extracurricular activity, or as a commercial venture is proportional to the perceived importance of the test results and the perceived influence on improving skills of knowledge and self-beliefs that ensure their optimal use. Demand is independent of what the test purports to measure and independent of the effectiveness of the preparation (Cameron, 1989).

The Educational Testing Service, which created and now administers the SAT, has abandoned its historical opposition to preparation. "The SAT is a high stakes test," says Arthur Knoll, an Educational Testing Service (ETS) vice president in charge of the SAT. "It pays to prepare for it just as you would for any rigorous endeavor. I would never encourage someone to go in cold" (cited in wilder, 1989, p. 65). Educational Testing service sends, Taking the SAT, a free pamphlet with test-taking strategies and sample questions, to all who register for the test (CEEB, 1989C). The College Board, an association of 2,600 colleges that use the SAT in admission screening, now sells computer software for SAT prepping. "Anyone who says preparation doesn't work is lying," says Bob Schaeffer, Public Education Director of Fair Test, a Cambridge, Massachusetts, nonprofit group that pushes for fairer and more accurate standardized tests (cited in wilder, 1989, p. 65). 
Preparation for the Scholastic Aptitude Test is prevalent in high schools across the United States. According to Powers (1988), nearly half of all secondary schools offer special programs of preparation for the SAT, and students participate, to varying degrees, in a variety of preparation activities.

\section{PURPOSE OF THE STUDY}

Significant relationships between identified preparation techniques and the perceived effectiveness of those techniques by students and staff can be very useful information for educators when counseling and/or assisting students who want to improve their ability to perform successfully.

Among many writers on this topic, one of the leaders is Cameron (1989). He states that the demand for special preparation for the SAT is independent of what the test will measure and independent of the proven effectiveness of the preparation. The demand is proportional to the belief of self-success with the preparation. Therefore, the purpose of this study is to describe perceptual opinions from students, teachers, counselors and administrators about the effectiveness of three preparation techniques: SAT computer programs, SAT preparation classes, and specific SAT information taught in general classes, in 10 Portland, Oregon metropolitan area high schools. 
Many studies including: The SAT Monitor Program (Response Analysis Corporation, 1978), Taking the SAT (CEEB, 1989c), Survey of Secondary Schools (Alderman \& Powers, 1980), and Preparing for the SAT: A Survey of Programs and Resources (Powers, 1988) have compared test taker perceptions of preparation effectiveness. None, however, have explored relationships of the perceived effectiveness of SAT computer programs, SAT preparation classes, and specific SAT information taught in general classes, by students, teachers, and counselors/administrators in schools in the Portland, oregon metropolitan area. This study is unique because it is a local study of perceptual effectiveness of three specific SAT preparation techniques.

\section{LIMITATIONS OF THE STUDY}

1. The selection of research data from only 10 schools limits generalization from the study.

2. The selection of schools who had composite (mathematical and verbal) class averages of 900 or above for three years on the SAT was drawn from 1985-1988 yearly scores. Current SAT scores may have changed since that time.

3. Because the schools selected had above average class composite scores, it is possible that the perceptions of students in these schools were more skewed toward the 
college bound student as opposed to a more representational average high school student.

4. The number of counselors/administrators in the study was very small and therefore makes generalization about their perceptions limited.

5. The fact that students did not identify gender precludes generalizations related to gender from the study.

6. Preliminary Scholastic Aptitude Test (PSAT) information was not requested. Therefore, practice testing generalizations will not be discussed.

7. It is possible that students who knew about all three SAT preparation techniques, but did not use SAT computer preparation programs nor SAT preparation classes, reported specific SAT information taught in general classes was effective because they wanted to believe their classroom preparation was adequate.

8. Students may have a limited basis for making judgements about specific preparation techniques if they had not completed the SAT.

\section{QUESTIONS}

1. What is the perceived effectiveness of three SAT preparation techniques: SAT computer programs, SAT preparation classes, and specific SAT information taught in general classes among students, teachers, and counselors/ administrators? 
2. Are students who regard the SAT as important more likely to know about, use, and perceive effective the three preparation techniques than students who do not?

3. Are students who regard the SAT as important more likely to perceive their teachers or administrators as valuing the SAT than students who do not?

4. Are students who perceive that their teachers or administrators regard the SAT as important more likely to perceive the preparation techniques effective than students who do not?

\section{DEFINITION OF TERMS}

The following terms and concepts are defined as follows for purposes of this dissertation.

Higher Level Classes: College preparation, advanced placement, or college credit classes.

Higher Level Thinking skills Training: Specific instruction for teachers about how to teach information so that students learn to comprehend, understand, analyze, synthesize, and evaluate concepts.

Preliminary Scholastic Aptitude Test (PSAT): A practice Scholastic Aptitude Test which is sometimes used as a tool to determine student potential for scoring on the SAT.

PSAT/SAT Training: Specific instruction for teachers about understanding and administering the PSAT or SAT. 
SAT (Scholastic Aptitude Test): A test of thinking skills which is commonly used as a piece of college entry criteria.

SAT Computer Preparation Programs: Computer programs available to students which are specifically created to help improve students' abilities to achieve on the SAT. These programs may be available to use at school, or at home. SAT Preparation Classes: Classes offered to students through their school that particularly target improving student abilities to achieve on the SAT. These classes may be offered during the school day, in the evening, on the weekend, or during the summer.

Self-efficacy: Demonstration of strong self-beliefs that ensure optimal use of learning and skills of knowledge. Target Schools: Ten schools in the Portland metropolitan area whose combined (math and verbal) total SAT tested population scored 900 or above two consecutive years between 1985-1988.

Testing Self-efficacy. Demonstration of strong self-beliefs that ensure optimal use of learning and skills of knowledge during testing. 
CHAPTER II

REVIEW OF RELATED LITERATURE

INTRODUCTION

The Scholastic Aptitude Test (SAT) is a test of thinking skills which is commonly used as a piece of college entry criteria. It is a test meant to be independent of any single curriculum, course, or program of study (Garvey, 1981). Nevertheless, because the SAT measures what has been learned, it is reasonable to assume that schooling may develop the abilities measured by the SAT. If, in fact SAT preparation does influence SAT results, then it is important for school counselors, educators, students, and measurement professionals to determine which, if any, types of preparation are perceived to be related to successful performance on the SAT (Cameron, 1989).

\section{HISTORY OF THE SAT}

In an attempt to introduce order into the transition from high school to college, the college Entrance Examination Board (CEEB) was organized at Columbia University in November 1900 (Garvey, 1981). The first CEEB admissions tests were essays designed by scholars. In 1901, 973 candidates wrote essays in history, Greek, Latin, 
German, French, English, mathematics, chemistry, and physics. In 1926, Carl Campbell Brigham, a Princeton University psychologist, introduced the multiple-choice SAT, administered to 8,040 candidates, consisting of nine subjects: paragraph reading, logical inference, analogies, definitions, artificial language, antonyms, arithmetical problems, classification, and number series. Three years later Brigham divided the SAT into two separate sections measuring verbal and mathematical aptitude. During the 1930s, CEEB concentrated on improving the consistency of its operations and strengthening the technical aspects of test construction. The increasing numbers of candidates taking the SAT prompted CEEB to provide a means of comparing SAT scores among the different standardized test forms. In April 1941, the group of 10,654 high school seniors tested became the standardization group of all subsequent forms of SAT. Since then, SAT scores have been equated directly to preceding test forms and indirectly to the April 1941 standardization form. This procedure, according to CEEB, insures that test scores have the same meaning from year to year and that the scoring represents the same level of ability regardless of the group of tests, the difficulty of the test, or the time of year tested (Garvey, 1981). 
WHY SAT?

The SAT is a useful tool for teachers and counselors giving guidance to high school students. It can be used to assist students in choosing college majors and thinking about careers. It can help students in selecting colleges where they are likely to find the academic competition congenial, and in scaling up or down students' and parents' expectations of the colleges to which students plan to apply (Cameron, 1989).

The SAT is the common yardstick with which colleges can compare the abilities of their applicants: The high school record alone does not enable this because of the variation in grading standards from high school to high school and from teacher to teacher. The SAT in combination with the high school record (HSR) improves the accuracy of prediction of college grades. The median correlation of high school record and freshman grade point average (GPA) for a sample 685 colleges is .48, while the SAT correlation is .42. The median correlation of the SAT in combination with HSR correlates is .55 , which is a $15 \%$ improvement over high school record alone (Cameron, 1989).

\section{A THEORETICAL FRAMEWORK}

Theoretical support for studying perceptual opinions of SAT preparation techniques has been demonstrated through the work of Craig (1976), Whitla (1988), and Bandura (1986). 
Craig (1976), in her book Human Development, theoretically defines perception as the process of extracting meaningful information from external sensation. She describes it as often being the first process in cognition. She believes that human perception is not a standard mechanism merely reflecting images, but works like a camera, and it involves an enormous variety of individual differences. This theory supports that people see things from their own vantage point. The perception that SAT scores will either open the door of selective colleges and generate scholarships or close off opportunities for the rest of one's life, makes almost every student who takes the test extremely anxious about doing as well as possible and getting a good score (Whitla, 1988). This perception is validated through statistics such as displayed in Table I, Scholastic Aptitude SAT Score Averages and acceptance rates which indicate the high selectivity of some colleges and universities. It has also induced students, parents, and school personnel to pursue successful preparation techniques (Whitla, 1988).

In the best of possible worlds, college admission tests would be impervious to short-term preparation or preparation. In this world, students would not be concerned with preparing for the "college boards" except tangentially as they pursued their high school studies and outside reading. However, because admissions and other standardized 
TABLE I

SCHOLASTIC APTITUDE SAT

SCORE AVERAGES

\begin{tabular}{|c|c|c|}
\hline & $\begin{array}{l}\text { Composite } \\
\text { SAT Score } \\
\text { Average }\end{array}$ & $\begin{array}{c}\text { \% Applicant } \\
\text { Acceptance } \\
\text { Rate } \\
1988-1989\end{array}$ \\
\hline Stanford University & 1,300 & 15 \\
\hline Harvard University & 1,360 & 15 \\
\hline Yale University & 1,370 & 17 \\
\hline Princeton University & 1,339 & 16 \\
\hline $\begin{array}{l}\text { University of California } \\
\text { at Berkeley }\end{array}$ & 1,181 & 37 \\
\hline Dartmouth College & 1,310 & 20 \\
\hline Brown University & 1,320 & 20 \\
\hline Cornell University & 1,375 & 29 \\
\hline $\begin{array}{l}\text { Massachusetts Institute } \\
\text { of Technology }\end{array}$ & 1,370 & 28 \\
\hline Rice University & 1,335 & 30 \\
\hline Johns Hopkins University & 1,303 & 53 \\
\hline University of Pennsylvania & 1,300 & 35 \\
\hline $\begin{array}{l}\text { California Institute of } \\
\text { Technology }\end{array}$ & 1,440 & 28 \\
\hline Williams College & 1,332 & 24 \\
\hline Swarthmore college & 1,310 & 28 \\
\hline Amherst College & 1,321 & 21 \\
\hline Haverford College & 1,300 & 31 \\
\hline
\end{tabular}


tests measure what has been learned, they are not impervious to the effects of instruction including self-efficacy. Bandura (1986) writes that the greatest benefits learning can bestow are not solutions to a specific problem but the reasoning and analyzing tools with which to effect solutions on one's own in whatever future learning situations might arise. In any activity, skills and self-beliefs that ensure their optimal use are required for successful functioning. If self-efficacy is lacking, people tend to demonstrate knowledge ineffectually, even though they know what to do. The changes accompanying learning may result as much, if not more, from installing beliefs in self-efficacy as from the particular skills imparted. To the extent that people's beliefs in their coping efficacy are strengthened, they approach situations more assuredly and make better use of the talents they have.

The demand for special preparation for admissions tests, whether conducted as a part of the school curriculum, as an extracurricular activity, or as a commercial venture is proportional to the perceived importance of the test results and the perceived influence on improving skills of knowledge and self-beliefs that ensure their optimal use. Demand is independent of measurement results and tested preparation effectiveness (Cameron, 1989). 
PREVIOUS RESEARCH

Some relevant data are available from previous studies of preparation techniques for the SAT. Some of the most recent studies are: Response Analysis Corporation (1978), Alderman and Powers (1980), Powers and Alderman (1979, 1983), Hopmeier (1984), Powers (1988), Whitla (1988), Morgan (1989), and Johnson and Wallace (1989).

\section{INCIDENCE OF TEST PREPARATION FOR THE SAT}

\section{The SAT Monitor Program}

One source of data is the SAT Monitor Program. In conjunction with the December 1977 administration of the SAT, the Response Analysis Corporation (1978) surveyed several waves of test takers before and after they took the SAT. In one wave, 1,000 examinees were asked, after they had taken the test, to indicate what they had done to prepare for the SAT. The survey revealed that nearly $80 \%$ of the students did something to prepare for the SAT. Most examinees (63\%) had completed the sample questions in About the SAT, the test familiarization booklet. About $27 \%$ had reviewed test preparation books. Twenty-four percent had reviewed English and vocabulary books on their own, $20 \%$ had reviewed mathematics books on their own, $11 \%$ had attended a review course at school, and $3 z$ had attended a fee-paid preparation session outside school. overall, student 
feelings were described as "mixed" about whether test preparation helped: about a third reported that test preparation helped them "do better," and another $46 \%$ said that although it did not help much, it did make them feel less nervous.

\section{study of Taking the SAT}

A second source of information is the College Board's evaluation of the impact of its (then) new test familiarization booklet, Taking the SAT (CEEB, 1989C). Powers and Alderman $(1979,1983)$ surveyed two random samples of 1,000 SAT registrants about their preparation activities for the June 1978 administration. One purpose of the survey was to assess whether the availability of the new test familiarization booklet had affected test takers' use of other preparation resources. The results suggested that it did not. Test takers used the new booklet to supplement not replace the other test taking activities in which they normally engaged.

The survey revealed that most test takers (92\%) made at least some use of the new booklet, and about $77 \%$ had also completed the questions in About the SAT, the older booklet (Powers \& Alderman, 1979, 1983). About 528 had read books on preparing for the test, 458 had reviewed English books and vocabulary, $30 \%$ mathematics books on their own, $16 \%$ had attended a preparation or a review session at school, and nearly $5 \%$ had attended review or preparation sessions outside school. 
Examinees reported that various methods of test preparation were differentially beneficial. For example, about 50\% of those who completed the questions in About the SAT and $75 \%$ of those who attended a review session outside school indicated that test preparation helped them "do better" (Powers \& Alderman, 1979, 1983). For each method of test preparation, from $18 \%$ to $35 \%$ said that although test preparation did not help them do better, it did decrease their nervousness.

$$
\begin{gathered}
\text { SCHOOL-SPONSORED PREPARATION } \\
\text { FOR THE SAT }
\end{gathered}
$$

\section{Survey of secondary schools}

In the 1977-1978 academic year, as a prelude to evaluating the effectiveness of school-based preparation for the SAT, Alderman and Powers (1980) surveyed secondary schools in seven northeastern states. The purpose of the survey was to identify for further evaluation those programs that were thought to be effective in increasing SAT verbal scores.

The survey revealed that $27 \%$ of the responding public schools and $42 \%$ of the private schools offered preparation for the verbal sections of the SAT. Most of the schools had started their programs within the two years preceding the survey. A spectrum of programs was noted, ranging from a brief workshop lasting less than one hour to extensive instruction incorporated in a regular English curriculum and 
lasting more than 100 hours. Nearly half the programs were electives that carried credit toward high school graduation. Most schools followed a commercial review book.

Morgan, in 1989, studied student Descriptive Questionnaire responses and score information from 100,000 seniors in the class of 1987. The analyses examined the relationship between both the Admissions Testing Program (ATP) SAT, achievement test scores, course curriculum content, and level of course work in six academic areas. The results showed that course work in the disciplines of mathematics, natural science, and foreign languages had the strongest relationships with SAT mathematical scores. SAT verbal scores appeared to be most strongly related to the number of years of foreign language course work. These relationships were generally consistent across ethnic groups and income levels. However, it appeared that the relationships were stronger for students with higher grade point averages. The specific courses that seemed to be most strongly related to SAT performance were upper-level courses in mathematics, natural science, and foreign languages. The specific course relationships were stronger for male than for female examinees (Morgan, 1989).

\section{Preparation Intervention}

In 1989, Johnson and Wallace assessed the effects of a test preparation program for urban black youth, who intended to take the SAT, on their performance on quantitative items. 
Findings for 116 program participants suggested that performance on a broad range of quantitative items was substantially improved even with a modest preparation intervention. Review of algebraic functions (and/or procedures) and test-taking strategies for approaching those and other types of problems faced on the SAT were helpful in assisting students with somewhat deficient quantitative backgrounds in applying that knowledge effectively within the testing situation. This examination of data also indicated that geometry items of each format and those items requiring multiple steps to solution were responsive to well-planned, coordinated, and well-delivered supplemental instructional programs. A principal implication of this research supported the continuation and broadening of such programs, especially throughout major urban areas where large at-risk populations of minority youth were located.

COMMERCIAL PREPARATION TECHNIQUES

Study of SAT Microcomputer

Coaching

A study, authorized by Florida state University and designed by Hopmeier (1984), looked at determining the effect of SAT scores when implementing preparation with a microcomputer and an individual instruction strategy which allowed peer interaction. The investigation used a "posttest-only control group design." It was assumed that if there was a difference in the mean SAT score of the 
control group (which did not receive computer preparation) and the mean SAT scores of the treatment group, then it was due to the microcomputer preparation provided. Students from all five geometry classes at a high school in santa Rosa County, Florida, participated in this study. The control group's mean SAT score for the mathematics section was 370 and the verbal mean was 310 . The mean score of the computer treatment group based on individual computer usage was 407 for the mathematics section and 346 for the verbal section. The treatment group working as small groups with the computer preparation programs had mean SAT scores of 407 for the mathematics section and 367 for the verbal section (Hopmeier, 1984).

The major conclusion resulting from this study was that SAT mathematics portion scores were improved through the use of computer preparation. However, there was no difference between the effectiveness of using computer preparation to improve mathematics SAT scores when students worked individually at the computer or when they worked in groups of three or four at a computer. The SAT verbal portion score was improved by the use of computer preparation with the strategy of three to four students using a single computer, suggesting that the students discussed the information presented by the computer preparation program among themselves (Hopmeier, 1984). 
Survey of Commercial SAT

Coaching

Whitla (1988), Director of the office of Instructional Research and Evaluation and Lecturer on Education from Harvard University, studied commercial SAT preparation services results from newly enrolled freshman at Harvard University who were administered a questionnaire during fall placement. He sought to discover how many of the newly registered freshman had been coached, and, if they had been, what their reactions were to the preparation courses and whether or not their SAT scores had improved. The study showed that preparation did not raise the SAT scores of Harvard students in any significant way. However, Whitla stated in his synopsis of the research that if students were taught how to interpret reading passages more accurately, and if they developed the ability to solve more difficult mathematical problems, they would score higher. He also commented that mastering such skills is demanding and requires time, and it may be that preparation schools do not provide enough instructional time.

\section{ALL SPECIAL TEST PREPARATION}

Preparing for the SAT: A

Survey of Programs and

Resources

In 1988 , to document the extent of all special test preparation for the SAT, Powers conducted two separate surveys--one of a stratified random sample of 1986-1987 SAT 
takers and the other of a stratified random sample of secondary schools whose students take the SAT. The objectives were to (a) determine the availability, and incidence of use, of a variety of programs and resources designed to prepare students to take the SAT; (b) describe some of the salient features of these resources; (c) estimate the amount of time (and money) that students spend on these resources; and (d) obtain examinees' reactions regarding the effectiveness of these resources.

The results of these surveys revealed that nearly half of all secondary schools offered special programs of SAT preparation. Those programs differed somewhat in their availability according to the geographic region, locale, and degree to which schools also provided various other kinds of courses (Powers, 1988).

A majority of the programs described were relatively new offerings. About one in every six programs (17q) were offered for the first time during the 1986-1987 academic year. An additional 658 were less than five years old, and $18 \%$ were described as having been offered for more than five years (Powers, 1988).

Interest by faculty or administration was described as a "major" factor in decisions to offer special preparation at $71 \%$ of the schools. Other major factors were student interest (cited by $61 \%$ of the schools), parent interest (46\%), and declining SAT scores (34\%) (Powers, 1988). 
Most often (about $53 \%$ of the time), SAT preparation was offered as an extracurricular activity. About $20 \%$ of the time it was provided as an elective course, and almost equally as often (18\%) it was required of at least some students. The remainder of the programs (about 17\%) were offered on some other, unspecified basis or on a combination of bases. Approximately one in every six courses carried credit toward graduation requirements (Powers, 1988).

Most programs (58\%) entailed group instruction that was distinct from regular courses. Other times (24\%) group instruction was provided in conjunction with regular courses. Somewhat less often (18\%) instruction was described as individualized, or was given on some other basis or as a combination of instructional methods (13\%) (Powers , 1988).

Most frequently (about $88 \%$ of the time) preparation courses included both verbal and mathematical components. Half of the remaining $12 \%$ of courses focused only on verbal preparation and the other half only on mathematical (Powers, 1988).

Students participated, to varying degrees, in a variety of preparation activities. Test familiarization materials provided by the college Board were the most widely used. Other commercially available books and texts used in regular courses| were also consulted relatively frequently. Engagement was much less frequent with test preparation 
software, special programs given either at school or outside school, books of practice tests from the College Board, or private tutoring. About $11 \%$ of all students in the survey said they had attended preparation or preparation sessions outside school at an average per student cost of about $\$ 150$ (Powers, 1988).

Several SAT preparation program objectives were studied. Increasing familiarity with the SAT was listed as a primary emphasis ( $81 \%$ ) more often than was any other objective. Improving verbal scores (77\%) and improving mathematical scores (76\%) were indicated next most frequently. Decreasing anxiety and developing confidence were each mentioned as emphases of about two thirds of the programs. Test-taking skills--poth general ones and those specific to the SAT--were primary emphases in about half the programs (Powers, 1988).

\section{SUMMARY}

The Scholastic Aptitude Test is intended to be insensitive to short-term curricular effects. Nevertheless, a review of the literature shows that it is reasonable to assume that preparation may develop the ability to demonstrate learning and/or the self-beliefs that ensure optimal use of the learning throughout the SAT. Studies do show that students use a preparation technique before taking the SAT. If in fact SAT preparation intrinsic and/or 
extrinsic to the high school curriculum does influence SAT results, then it is important for school counselors, educators, students, and measurement professionals to determine which, if any, types of preparation are perceived to be related to successful performance on the SAT and for whom they are perceived to be most important. 
CHAPTER III

DESIGN OF THE RESEARCH

SAMPLE DESIGN

The sample for this study was drawn from the student populations in 10 high schools in the Portland metropolitan area who had composite class averages of 900 or above for three consecutive years between 1985-1988 on the Scholastic Aptitude Test (J. Erickson, personal communication, December 1988). The sample was selected from senior students, teachers, and counselors/administrators in the fall of 1989 from Canby, Clackamas, David Douglas, Gladstone, Lake Oswego, Lakeridge, Lincoln, Parkrose, Tigard, and West Linn. As shown in Table II, a total of 37 counselors/ administrators, 631 students, and 133 teachers responded to the questionnaire. Twenty percent of the senior students at each of the 10 high schools completed the survey, as did $33 \%$ of the teachers, counselors, and administrators.

The staff and students were selected randomly in concert with the principal of each building. Every third teacher, counselor, and administrator from alphabetical staff lists and all students from every fourth heterogeneous, required class were chosen. 
TABLE II

NUMBER OF QUESTIONNAIRE RESPONDENTS

\begin{tabular}{lccc}
\hline & Students & Teachers & $\begin{array}{c}\text { Counselors/ } \\
\text { Administrators }\end{array}$ \\
\hline Canby High School & 58 & 10 & 5 \\
Clackamas High School & 109 & 23 & 5 \\
David Douglas High School & 72 & 20 & 4 \\
Gladstone High School & 54 & 10 & 2 \\
Lake Oswego High School & 44 & 11 & 2 \\
Lakeridge High School & 10 & 9 & 3 \\
Lincoln High School & 57 & 15 & 4 \\
Parkrose High School & 111 & 11 & 5 \\
Tigard High School & 74 & 17 & 5 \\
West Linn High School & 42 & 7 & 2 \\
\hline
\end{tabular}

DEVELOPMENT OF THE QUESTIONNAIRE

According to Borg (1987, p. 424), the most logical and accurate rethod of finding out whether identified SAT preparation techniques are effective or not, is to ask. since a data-collecting instrument was not available, a questionnaire (Scholastic Aptitude Preparation Survey, SAPS) was developed to determine what the perceived effectiveness of the preparation techniques was in each school. Research by Garvey (1981) and Thomson (1978) guided development of the instrument by providing an inclusive list of effective 
preparation techniques which included SAT preparation computer programs, SAT preparation classes, and specific SAT information taught in general classes.

Rough drafts of the three questionnaires were developed and submitted to members of the investigator's committee at Portland state University for further scrutiny. The questionnaires were then field tested at a local high school for further refinement.

\section{DESCRIPTION OF THE SCHOLASTIC APTITUDE} PREPARATION SURVEY

The first item on each survey asked respondents to give their perceptions of the importance of the SAT for students' future education. The fourth, seventh, and tenth items asked respondents to give their perceptions of effectiveness for the three identified SAT preparation techniques: item 4--SAT Computer Preparation Programs, item 7--SAT Preparation Classes, and item 10--Specific SAT Information Taught in General Classes. These three preparation techniques were chosen because they were the most commonly described in the research review.

The second, third, fifth, sixth, eleventh, and twelfth items asked respondents about their perceptions of knowledge and availability of the SAT Computer Programs, the SAT Preparation classes, and the specific SAT Information Taught in General classes. These questions were asked to clarify 
student and staff perception of availability and use of these programs.

The eighth and ninth items asked respondents about their perceptions of teacher and administrator valuing of the SAT. These questions were asked to test for relationships between adult values for the SAT and student perception of SAT preparation technique success.

The last three items on the student questionnaire asked students to give information about whether they had taken college prep/advance level classes, if they had taken or planned to take the SAT, or if they planned to attend a four year college. These questions were asked to determine whether a specific group of students perceived one or more of the preparation techniques to be successful. The complete SAT student Survey can be found in Appendix A. The last three items on the teacher questionnaire asked teachers if they had taught college level classes, if they had had PSAT/SAT training, and if they had had higher level thinking skills training. These questions were asked to see if a specific group of teachers perceived one or more of the preparation techniques to be successful. The complete SAT Teacher Survey can be found in Appendix A.

The last three items on the counselor/administrator questionnaire asked if advanced placement classes were offered at their school, if higher level thinking skills training was offered at their school, and if students were 
counseled before taking the PSAT/SAT. These questions were asked to determine whether any of these activities related to stronger perception of success for one or more of the preparation techniques. The complete SAT Counselor/ Administrator Survey can be found in Appendix A.

\section{COLLECTION OF THE DATA}

The questionnaires: The Scholastic Aptitude Preparation Survey for Students, The Scholastic Aptitude Preparation Survey for Teachers, and The Scholastic Aptitude Preparation Survey for Counselors/Administrators, consist of 15 questions related to the perceived effectiveness of three identified preparation techniques. Students, teachers, counselors/administrators responded on a likert type scale.

The questionnaire was administered to students by classroom teachers during class time. In all cases students were told that their participation was voluntary and they were encouraged to be honest and to ask questions if there was something in the survey that they did not understand. It was explained that the survey was confidential and that the results would only be reported by school. Individual student scores would not be reported. All of the senior class student surveys were returned except for those from Lakeridge High School. Approximately two thirds of their questionnaires were lost in transit, and they were not redone. It was decided to retain these data for analysis. 
The Counselor/Administrator survey and the Teacher Survey were completed by each person in a quiet, individual office setting. Again, all respondents were asked to be honest, they were assured that their survey responses were confidential, and that the results would be reported only by school. All of the teacher and counselor/administrator staff surveys were returned to the investigator.

\section{DATA ANALYSIS}

The four questions in this study were tested using the data generated by the Scholastic Aptitude Preparation Surveys. According to Borg (1987, p. 547), the chi-square test is used to estimate the likelihood that some factor other than chance accounts for an apparent relationship between variables. Therefore, chi-square tests were used to test independent and dependent variables. The perceptions of the effectiveness of identified SAT preparation techniques were grouped into the following independent variables:

1. SAT Computer Preparation Programs

2. SAT Preparation Classes

3. SAT Information Taught in General Classes

Using chi-square tests, comparisons were made with the following dependent variables: 
Teachers:

1. who teach or have taught college classes and those who do not or have not

2. who have received higher level thinking skills training and those who have not

3. who have received PSAT/SAT training and those who have not

4. Who value the SAT and those who do not students :

1. who are or have been enrolled in college level classes and those who are not or have not

2. who have taken or plan to take the SAT and those who have not

3. who plan to go to a four year college and those who do not

4. who value the SAT and those who do not Counselors/Administrators:

1. who offer college level classes at their school and those who do not

2. who offer higher level thinking skills training at their school and those who do not

3. who counsel students before taking the PSAT/SAT and those who do not

4. who value the SAT and those who do not

The findings for all four research questions were examined by analyzing the relationship between the 
independent variable preparation techniques: (a) SAT preparation computer programs, (b) SAT preparation classes, and (c) specific SAT information taught in general classes and the dependent variable groups' perceptions of the techniques. Chi-square statistical analyses using Statistical Analysis Systems (SAS) were performed to examine the four questions. 
CHAPTER IV

\section{PRESENTATION AND ANALYSIS OF DATA}

\section{INTRODUCTION}

This chapter reports the findings on the perceived effectiveness of the following SAT preparation techniques: (a) SAT preparation computer programs, (b) SAT preparation classes, and (c) specific SAT information taught in general classes. The purpose of this study was to provide an understanding of the effectiveness of SAT preparation techniques as perceived by students and staff in an attempt to determine which, if any, types of preparation are perceived to be related to successful performance on the SAT and for whom they are perceived to be most important.

The following four questions guide the organization of Chapter IV.

1. What is the perceived effectiveness of three SAT preparation techniques: SAT computer programs, SAT preparation classes, and specific SAT information taught in general classes among students, teachers, and counselors/administrators in 10 metropolitan area high schools? 
2. Are students who regard the SAT as important more likely to know about, use, and perceive effective the three preparation techniques than students who do not?

3. Are students who regard the SAT as important more likely to perceive their teachers or administrators as valuing the SAT than students who do not?

4. Are students who perceive that their teachers or administrators regard the SAT as important more likely to perceive the preparation techniques effective than students who do not?

\section{STATISTICAL ANALYSIS}

\section{Question I}

What is the perceived effectiveness of three SAT preparation techniques: SAT computer programs, SAT preparation classes, and specific SAT information taught in 10 metropolitan area high schools?

Effectiveness of the Preparation Techniques. Items 4, 7 , and 10 on the questionnaire asked respondents to answer strongly agree, agree, don't know, disagree, or strongly disagree to the effectiveness of three SAT preparation techniques: item 4--SAT Computer Programs, item 7--SAT Preparation Classes, and item 10--Specific SAT Information Taught in General classes. The results of these items are presented in Figures $1-3$ and supporting data can be found in Appendix B. 


\section{SAT Computer Programs}

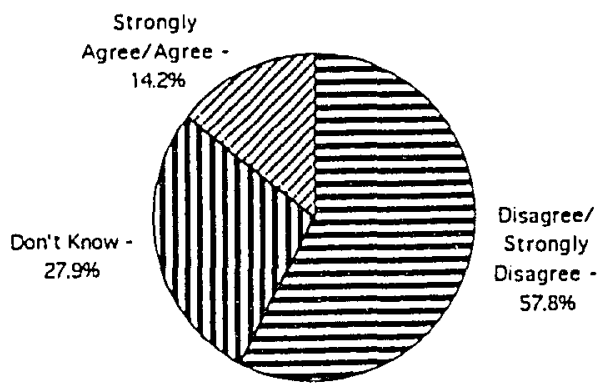

SAT Preparation Classes

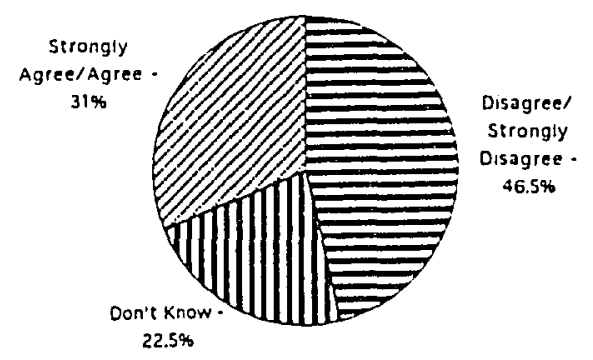

Specific SAT Information Taught

in General Classes

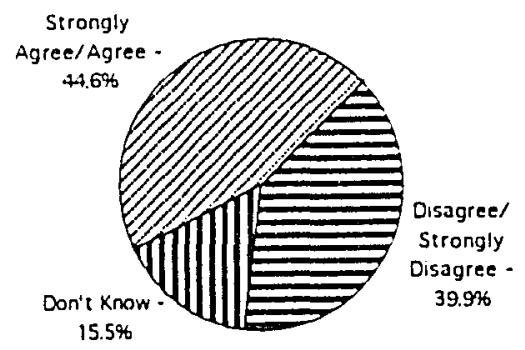

Figure 1. Student perceived effectiveness of three SAT preparation techniques.

Figure 1 illustrates that the greatest percentage of students disagreed $(58 \%)$ that SAT computer programs were effective, disagreed (47\%) that SAT preparation classes were effective, and agreed (45\%) that specific SAT information 
taught in general classes was an effective preparation technique.

SAT Computer Programs

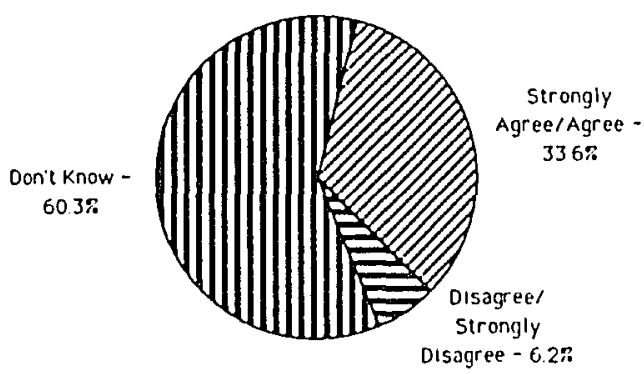

\section{SAT Preparation Classes}

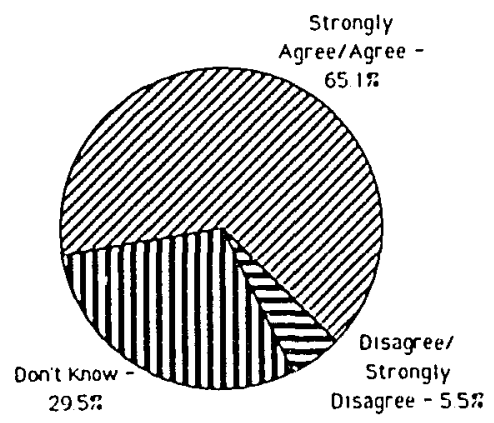

Specific SAT Information Taught In General Classes

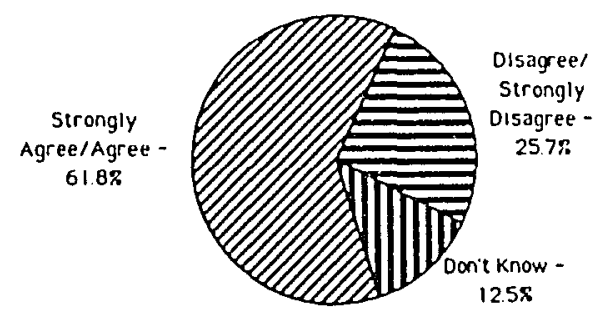

Figure 2. Teacher perceived effectiveness of three SAT preparation techniques. 
SAT Computer Programs

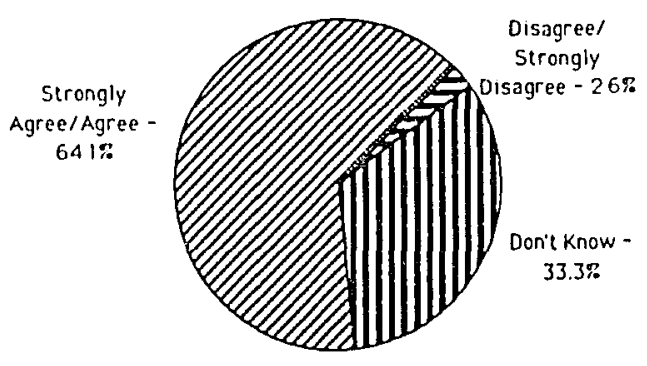

SAT Preparation Classes

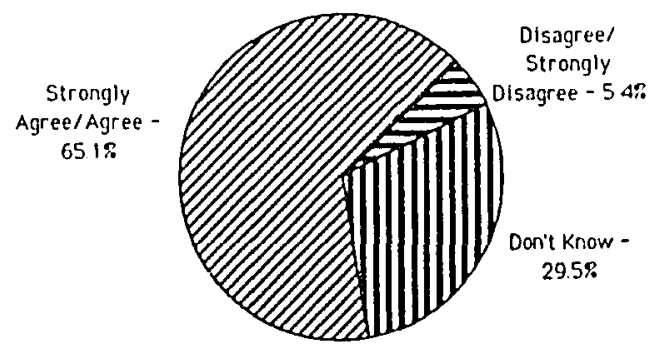

Specific SAT Information Taught In General Classes

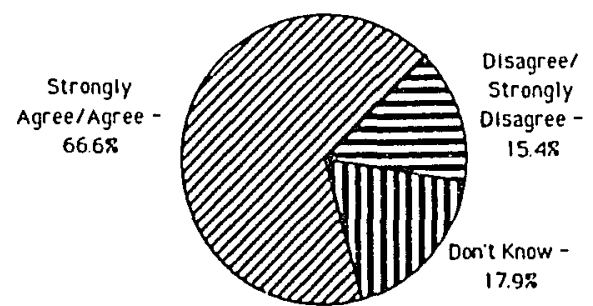

Fiqure 3 . Counselor/administrator perceived effectiveness of three SAT preparation techniques.

Figure 2 illustrates that the greatest percentage (60\%) of teachers did not know if computer programs were effective or not, agreed (65\%) that SAT preparation classes 
were effective, and agreed $(62 \%)$ that specific SAT information taught in general classes was an effective preparation technique.

Figure 3 illustrates that the greatest percentage of counselors/administrators agreed (64\%) that SAT computer programs were effective, agreed (65\%) that specific SAT preparation classes were effective, and agreed (67\%) that specific SAT information taught in general classes was an effective preparation technique.

There was a significant difference $(\underline{p}=.0000)$ in response between student, teacher, and counselor/ administrator groups for the perceived effectiveness of all three preparation techniques. The graph in Appendix B shows that over half of the counselors/administrators agreed that all three techniques were effective. Over half of the teachers agreed that preparation classes and specific SAT information taught in general classes was effective. Less than half of the students agreed that any of the techniques were effective.

Specific Student Groups. Statements 13,14 , and 15 on the Scholastic Aptitude Preparation Survey for students asked respondents to answer strongly agree, agree, don't know, disagree, or strongly disagree to the following: I am enrolled in college preparation or advanced placement classes; I have taken or I plan to take the Scholastic Aptitude Test; I plan to attend a four year college. 
College Prep/Advanced Placement Classes.

Fifty-five percent of all students indicated that they were enrolled in a college preparation or advanced placement class. As seen in Figure 4, when students were asked about the effectiveness of SAT computer programs there was not a statistically significant difference in responses between students who were enrolled in a college prep/advanced placement class and those who were not.

There was a significant difference $(\mathrm{p}=.0002)$ in responses between students who were enrolled in college prep/advanced placement classes and those who were not when asked if SAT preparation classes were effective. Thirty-eight percent of students enrolled in college prep/advanced classes agreed that SAT preparation classes were effective. Twenty-one percent of those students who were not enrolled in college prep/advanced placement classes agreed that SAT preparation classes were effective.

There was a significant difference $(\mathrm{p}=.0000)$ in responses between students who were enrolled in college prep/advanced placement classes and those who were not regarding the effectiveness of specific SAT information taught in general classes. Of those who were enrolled, 55\% agreed that specific SAT information taught in general classes was an effective preparation technique. Of those not enrolled, $50 \%$ disagreed that it was effective. 
SAT Computer Programs

Students Enrolled in College Prep/Advanced Placement Classes

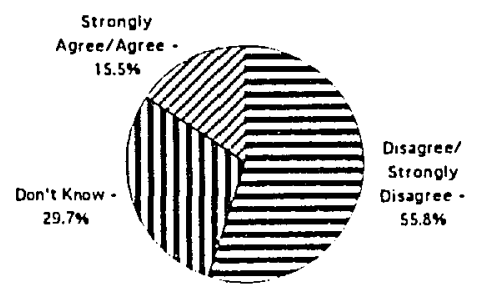

Students Not Enrolled in College Prep/Advanced Placement Classes

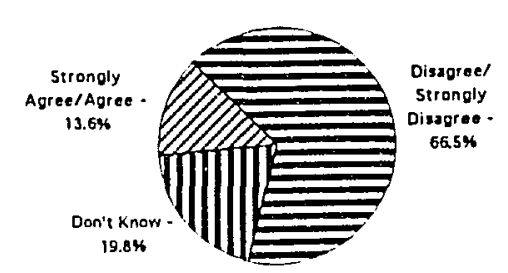

There were no significantly different responses.

\title{
SAT Preparation Classes
}

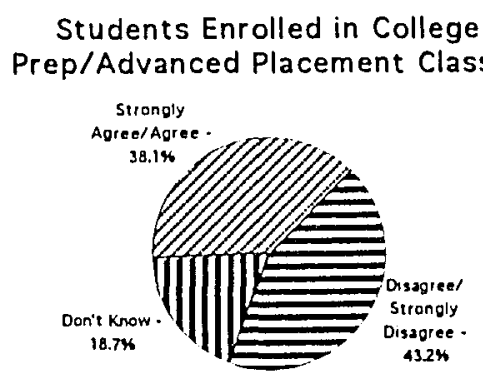

Students Not Enrolled in College Prep/Advanced Placement Classes

There was a significant difference $(\mathrm{n}=.00(02)$ in responses.

\section{Specific SAT Information Taught In General Classes}

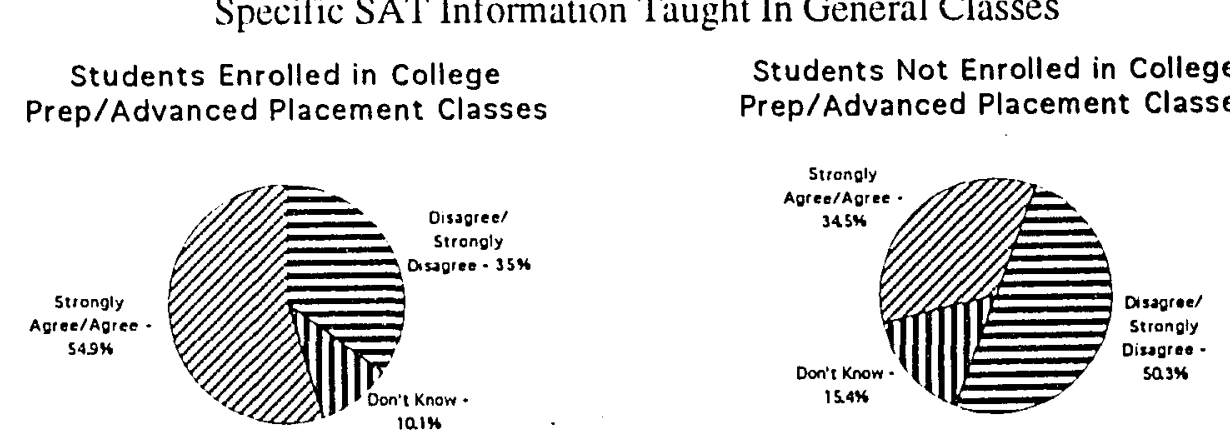

\begin{abstract}
Students Not Enrolled in College Prep/Advanced Placement Classes
\end{abstract}

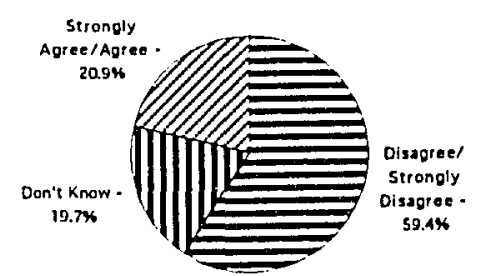

There was a significant difference $(\mathrm{p}=.00(0)$ in responses.

$$
\begin{aligned}
& \text { Fiqure 4. Did students who were enrolled in } \\
& \text { college prep/advanced classes perceive the } \\
& \text { preparation techniques differently than those } \\
& \text { who were not enrolled? }
\end{aligned}
$$

Had Taken or Plan to Take the SAT. Seventy percent of all the students agreed that they had or would take the SAT. 
As seen in Figure 5, there was a statistical difference $(p=.0023)$ between students who had taken or planned to take the SAT and those who had not in response to the effectiveness of SAT computer programs. One half of those students who had taken or planned to take the SAT, disagreed with the statement that SAT computer programs were effective. Almost two thirds of the students who did not plan to take the SAT disagreed with the statement that the SAT computer programs were effective.

There was a statistical difference $(\mathrm{g}=.0000)$ between students who had taken or had planned to take the SAT and those who had not in response to the effectiveness of SAT preparation classes. Forty-four percent of students who had taken or planned to take the SAT disagreed with the statement that SAT preparation classes were effective, $67 \%$ of those who did not plan to take the SAT disagreed.

In response to the effectiveness of specific SAT information taught in general classes, there was a statistically significant difference $(\underline{p}=.0032)$ between students who had taken or planned to take the SAT and those who had not. Fifty-one percent of the students who had taken or planned to take the SAT agreed that specific SAT information taught in general classes helped students to be better prepared for the SAT. More than half of those students who were not planning to take the SAT disagreed that specific SAT information taught in class was effective. 
SAT Computer Programs

Students Who Had Taken Or

Planned To Take The SAT

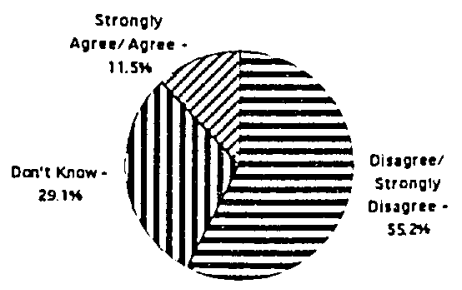

Students Who Did Not Plan

To Take The SAT

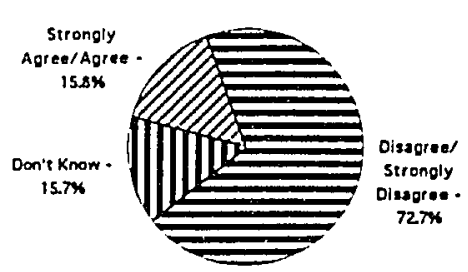

There was a significant difference $(p=.0023)$ in responses.

SAT Preparation Classes

Students Who Had Taken Or Planned To Take The SAT

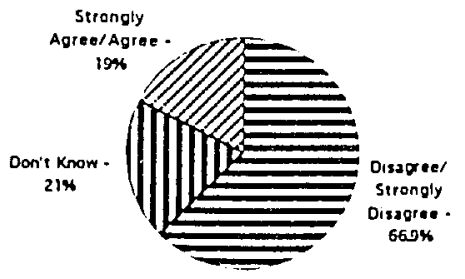

Students Who Did Not Plan

To Take The SAT

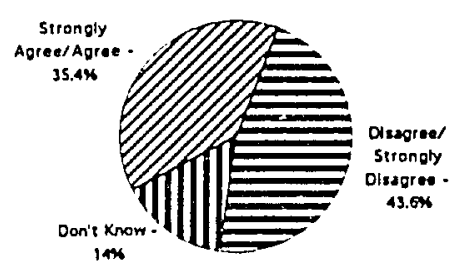

There was a significant difference $(p=.000())$ in responses.

Specific SAT Information Taught In General Classes

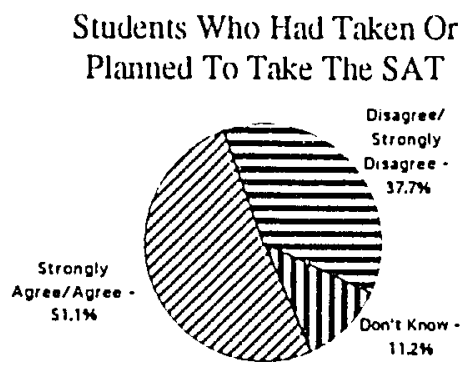

Students Who Did Not Plan To Take The SAT

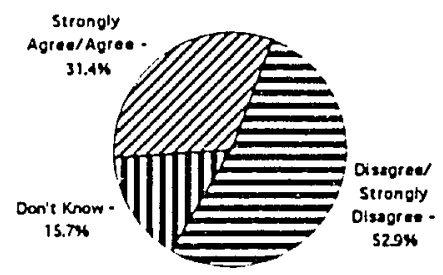

There was a significant difference $(p=.0032)$ in responses.

Figure 5. Did students who had taken or planned to take the SAT perceive the preparation techniques differently than those who had not?

Students Who Planned to Attend a Four Year College. Sixty-eight percent of all students indicated that they planned to attend a four year college. As shown in Figure 
6, there was not a statistically significant difference in response between those students who planned to go to a four year college and those who did not regarding their perceptions of the effectiveness of SAT computer programs. There was, however, a significant difference $(\mathrm{p}=.0000)$ response between the two groups responses when asked if SAT preparation classes were effective. of those who planned to attend a four year college, $198 \mathrm{did}$ not know and $46 \%$ disagreed that SAT preparation classes helped students to be better prepared for the SAT. Of those who did not plan to attend a four year college, $16 \%$ did not know and $68 \%$ disagreed that SAT preparation classes were effective. There was a significant difference $(\mathrm{p}=.0000)$ in response between students who planned to attend a four year college and those who did not when asked if specific SAT information taught in general classes was effective. of those students who planned to go to a four year college, only $8 \%$ did not know and $52 \%$ agreed that specific SAT information taught in general classes was effective. of those who did not plan to attend a four year college, $21 \%$ did not know and $47 \%$ disagreed that specific SAT information taught in general classes was effective.

Specific Teacher Groups. Items 13, 14, and 15 on the Scholastic Aptitude Preparation survey for Teachers asked respondents to answer strongly agree, agree, don't know, disagree, or strongly disagree to the following statements: 
I teach college level and/or advanced placement classes; I have received higher level thinking skills training; I have received PSAT/SAT training.

\section{SAT Computer Programs}
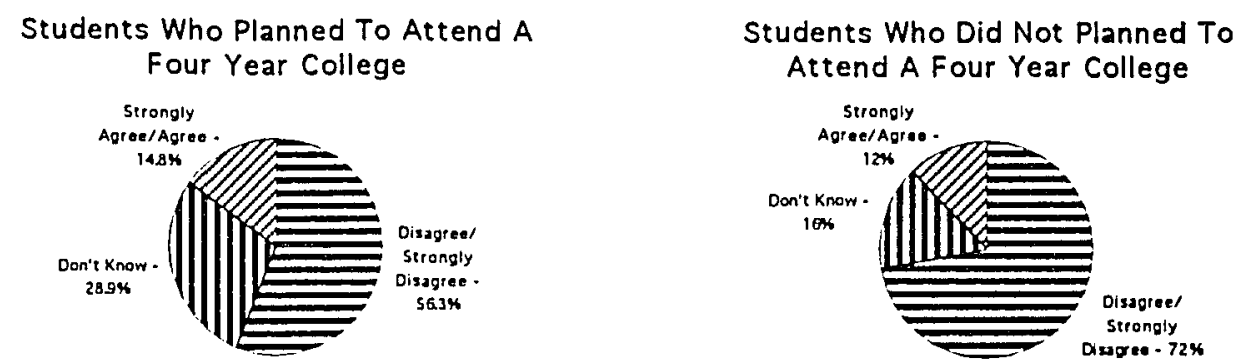

There were no significantly different responses.

\section{SAT Preparation Classes}

Students Who Planned To Attend A

Four Year College

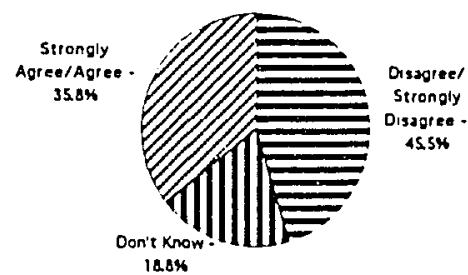

Students Who Did Not Plan To Attend a Four Year College

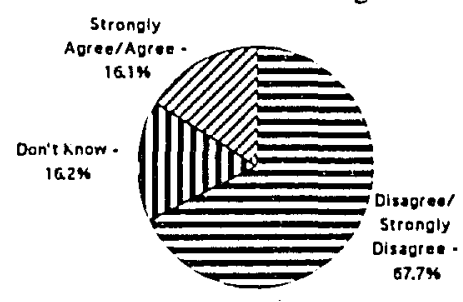

There was a significant difference $(p=.0000)$ in responses.

\section{Specific SAT Information Taught In General Classes}

Students Who Planned To Attend A

Four Year College

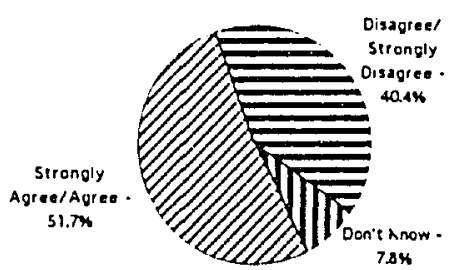

Students Who Did Not Plan To Attend a Four Year College

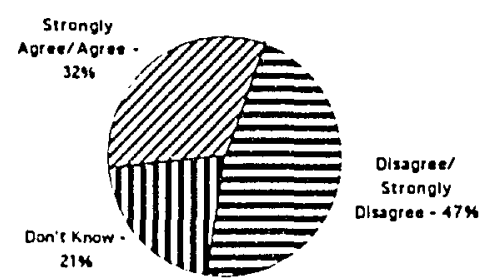

There was a significant difference $(p=.0(0) 00)$ in responses.

Figure 6. Did students who planned to attend a four year college perceive the preparation techniques differently than those who had not? 
College Level classes. Forty percent of the teachers agreed that they taught college level classes, $41 \%$ disagreed, and $19 \%$ did not know. There was not a significant difference in response from teachers whether they taught college prep classes or not when asked if SAT computer programs, SAT preparation classes, or specific SAT concepts taught in general classes helped students to be better prepared for the SAT.

PSAT/SAT Training. Sixty-two percent of the teachers indicated that they had had PSAT/SAT training. Only $18 \%$ agree that they had participated in PSAT/SAT training. There was no statistical difference between groups who had or had not participated in PSAT/SAT training in reference to SAT computer program or SAT preparation class effectiveness. There was a statistical difference $(\underline{\underline{p}}=.0000)$ between teachers who had and those who had not received PSAT/SAT training in response to specific SAT information taught in general classes. Of those teachers who participated in PSAT/SAT training, $92 \%$ agreed that SAT concepts taught in the classroom helped students to be better prepared for the SAT. Of those teachers who did not participate in PSAT/SAT training, 598 disagreed that SAT concepts taught in the classroom helped students to be better prepared for the SAT. Higher Level Thinking Skills Training. Seventy-seven percent of the teachers indicated that they had received higher level thinking skills training, 128 indicated they 
had not, and $11 \%$ did not know. There was not a significant difference in response whether teachers had higher level thinking skills training or not when asked if SAT computer programs, SAT preparation classes, or specific SAT information taught in general classes helped better prepare students for the SAT.

Counselors/Administrators Background. Items 13, 14, and 15 on the Scholastic Aptitude Preparation Survey for Counselors/Administrators asked respondents to answer strongly agree, agree, don't know, disagree, or strongly disagree to the following questions: college level and/or advanced placement classes are offered at my school; Higher level thinking skills training has been offered to teachers at my school; students are counseled before taking the PSAT/SAT. There were no statistically significant differences in responses between or among the subgroups of counselors/administrators.

\section{Question II}

Are students who regard the SAT as important more likely to know about, use, and/or perceive effective the three preparation techniques than students who do not? Availability and Knowledge of the SAT Preparation Techniques. Items two and three on the questionnaire pertained to availability and use of SAT computer programs. Items five and six pertained to the availability and use of SAT preparation classes. Items eleven and twelve pertained 
to availability and knowledge of methods which teachers use to provide specific SAT information in their classes. Respondents were asked to answer strongly agree, agree, don't know, disagree, or strongly disagree to each of the above mentioned questions. Figures 7-12 display in graphical form the responses.

There was a significant difference $(\underline{p}=.0000)$ in responses among students, teachers, and counselors/ administrators to items two and three. As shown in Figure 7, more than half of the teachers, students, and counselor/ administrators agreed that SAT computer programs were available. However, approximately one third of the students and teachers did not know if they were available while less than $10 \%$ of the administrators did not know.

Over $70 \%$ of the students said that they were not using SAT computer programs, yet $32 \%$ of the teachers and $69 \%$ of counselors/administrators said that students were using these programs. More than half of the teachers did not know whether or not students were using these programs or not. As shown in Figure 8 , there were significant differences $(\underline{p}=.0000)$ in responses among students, teachers, and counselors/ administrators in regard to the use of computer programs. 
SAT Computer Programs Are Available

\section{Students}

Strongly Agree/Agree

$52.1 \%$

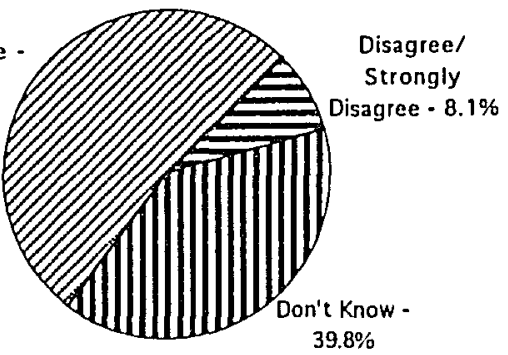

Teachers

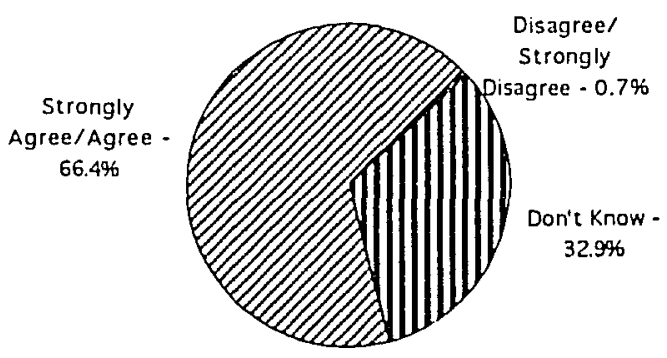

Counselors/Administrators

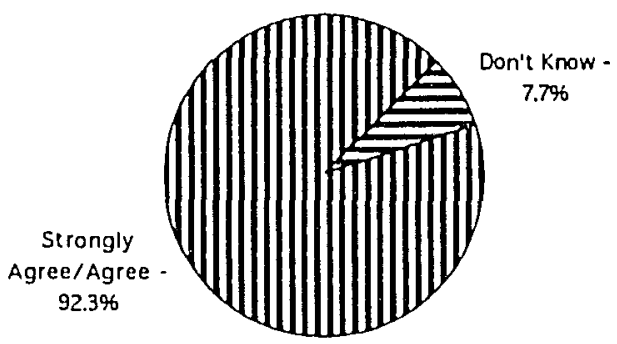

There were significant differences $(\mathrm{p}=.(0)(0))$ in responses among students, teachers, and counselors/administrators.

Figure 7. Perceptions of the availability of SAT computer preparation programs. 
Students Have or Are Using SAT Computer Programs

\section{Students}

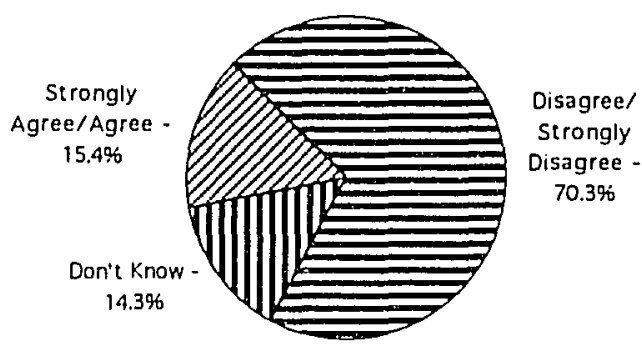

Teachers

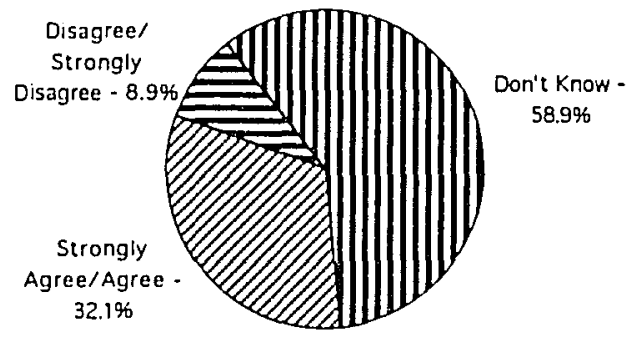

Counselors/Administrators

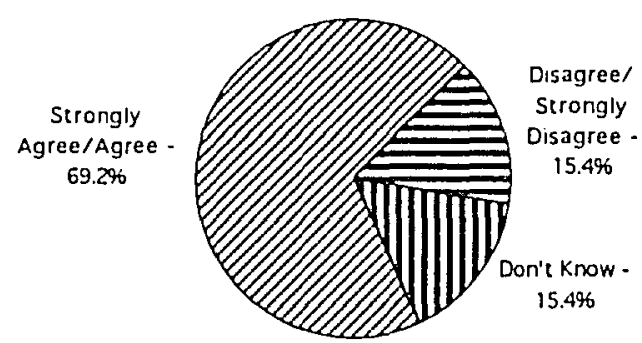

There were significant differences $(p=.(0)(0))$ in responses among students, teachers, and counselors/administrators.

Figure 8 . Perceptions of the use of SAT computer preparation programs. 
SAT Preparation Classes Are Offered

Students

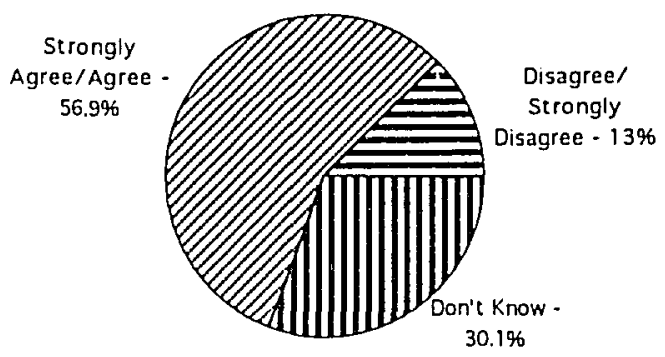

Teachers

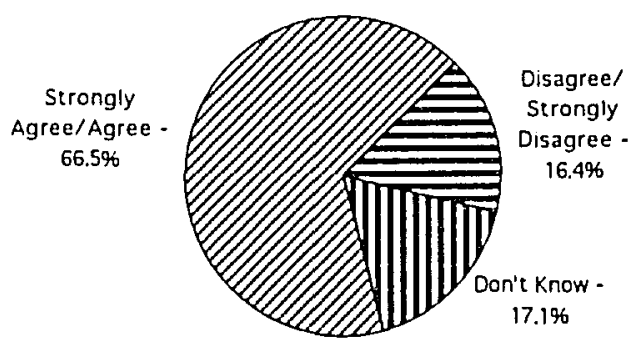

\section{Counselors/Administrators}

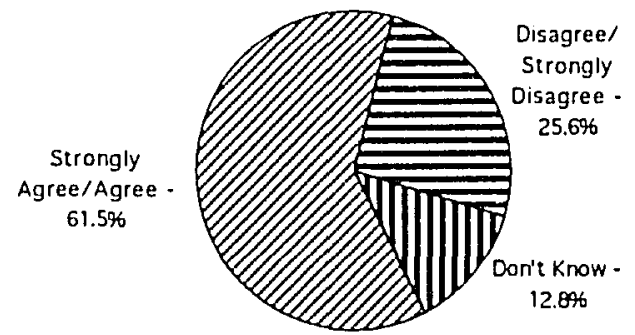

There were significant differences $(p=.0000)$ in responses among students, teachers, and counselors/administrators.

Figure 9. Perceptions of the availability of SAT preparation classes. 
Students Have or are Participating in SAT Preparation Classes

\section{Students}

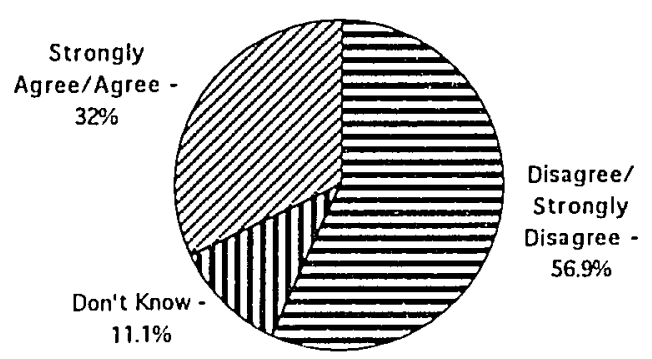

Teachers

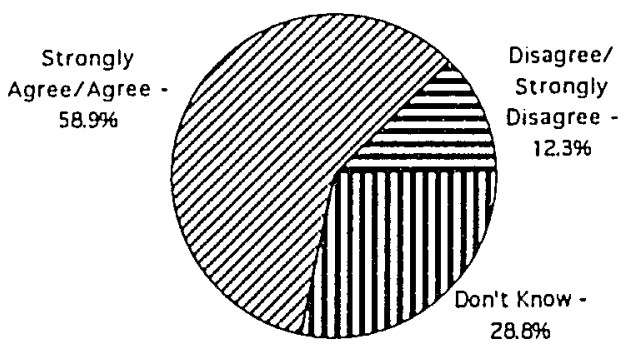

\section{Counselors/Administrators}

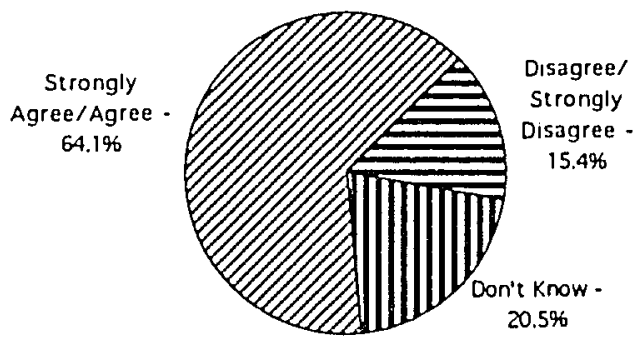

There were significant differences $(p=.()(0)(0)$ in responses among students, teachers, and counselors/administrators.

\section{Figure 10. Perceptions of the use of SAT preparation classes.}


Teachers Specifically State to Students That Certain Topics

Will Be Presented on the SAT

Students

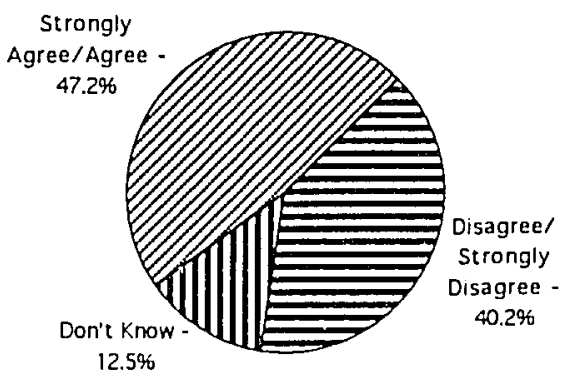

Teachers

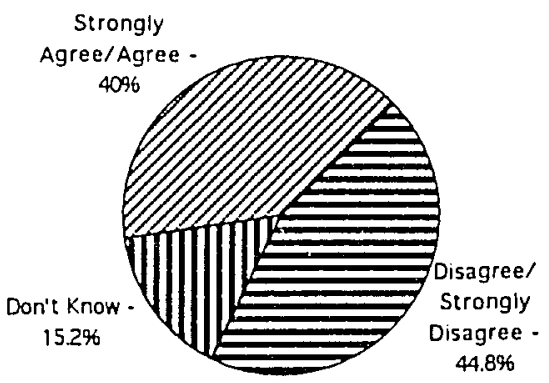

Counselors/Administrators

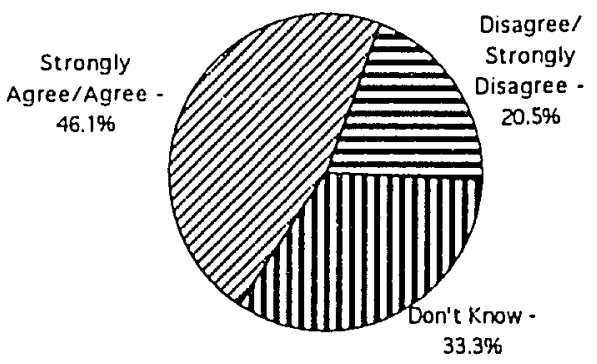

There were significant differences $(\mathbf{b}=\mathbf{. 0 2 2 0})$ in responses among students, teachers, and counselors/administrators.

\section{Figure 11. Methods which teachers use to} provide specific SAT information in classes. 
Teachers Sometimes Give Tests Which Require Students

to Analyze, Synthesize, and Evaluate

Students

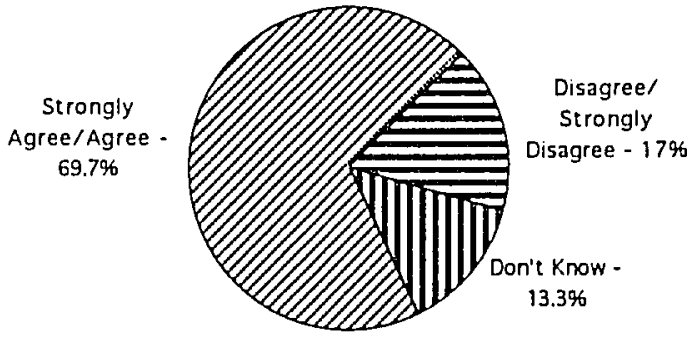

Teachers

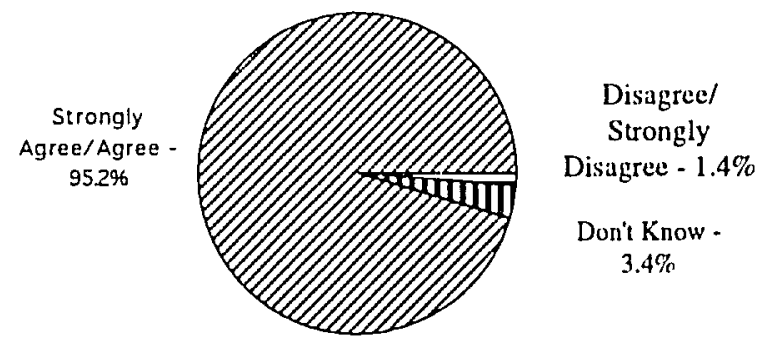

Counselors/Administrators

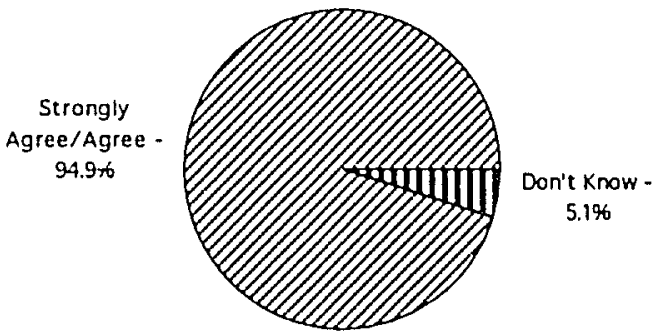

There were significant differences $(p=.(0)(0)$ in responses among students, teachers, and counselors/administrators.

Figure 12. Higher level thinking skills methods which teachers use to provide specific SAT information in classes. 
As shown in Figure 9, more than half of the students, teachers, and counselors/administrators agreed that SAT preparation classes were offered. However approximately one third of the students did not know whether or not they were. As shown in Figure 9 there were significant differences $(\mathrm{p}=.0000)$ in responses among students, teachers, and counselors/administrators in regard to the availability of SAT preparation classes.

As shown in Figure 10, over half of the teachers and counselors/administrators agreed that students had participated in SAT preparation classes, yet more than half of the students disagreed that they had. As illustrated in Figure 10, there were significant differences $(p=.0000)$ in responses among students, teachers, and counselors/ administrators in regard to participating in SAT preparation classes.

As shown in Figure 11, there was a significant difference $(p=.0220)$ in the response among students, teachers, and counselors/administrators in reference to teachers stating specifically to students that certain topics would be present on the SAT. Forty-six percent of the counselors/administrators agreed, $40 \%$ of the teachers agreed, and 478 of the students agreed. However, $13 \%$ of the students did not know and $15 \%$ of the teachers did not know, yet 338 of the counselors/administrators did not know. Forty percent of the students disagreed and $45 \%$ of the 
teachers disagreed, yet only $21 \%$ of the counselors/ administrators disagreed.

As shown in Figure 12, there was a significant difference $(p=.0000)$ in response to teachers sometimes giving tests which required analysis, synthesis, and evaluation. Over $90 \%$ of the teachers and counselors/ administrators agreed. Almost 708 of the students agreed. None of the administrators disagreed, yet $17 \%$ of the students disagreed, and $1 \%$ of the teachers disagreed. Value and Availability, Use and Effectiveness. Item number one on the questionnaire asked respondents to answer strongly agree, agree, don't know, disagree, or strongly disagree to: Scholastic Aptitude Tests are important to students for their future education. There were no significantly different responses among teachers or counselors/administrators, whether they agreed that the SAT was important for students or not, in response to the effectiveness of all three of the preparation techniques. However, student responses did demonstrate statistically significant differences. As seen in Appendix B, students who valued the SAT were not more likely to know about SAT computer programs, SAT preparation classes, nor to know that teachers mention specific topics which would be present on the SAT than students who did not value the SAT.

Table III illustrates that students who value the SAT were not more likely to use SAT computer programs or SAT 
preparation classes than students who did not value the SAT. However, students who valued the SAT were significantly ( $\underline{p}=$ $.0009)$ more likely to perceive that specific SAT information taught in general classes helped them be better prepared for the SAT.

TABLE III

ARE STUDENTS WHO VALUE THE SAT MORE LIKELY TO USE THE PREPARATION TECHNIQUES THAN THOSE WHO DO NOT VALUE THE SAT?

\begin{tabular}{lcc}
\hline & $\begin{array}{c}\text { f Value } \\
\text { the SAT }\end{array}$ & $\begin{array}{c}\text { of Do Not } \\
\text { Value the SAT }\end{array}$ \\
\hline $\begin{array}{l}\text { I've Completed One of } \\
\text { the Computer Programs }\end{array}$ & 14.5 & 15.3 \\
$\begin{array}{l}\text { I've Participated in SAT } \\
\text { Preparation Courses }\end{array}$ & 34.6 & 30.6 \\
$\begin{array}{l}\text { There Has Been Specific } \\
\text { Information in My } \\
\text { Classes Phat Has } \\
\text { Helped Me Be Better } \\
\text { Better Prepared For } \\
\text { the SAT | }\end{array}$ & & 36.9 (.0009 \\
\end{tabular}

As seen in Table IV there was a significant difference $(\mathrm{p}=.0007)$ in response between students who value the SAT and those who did not when asked about the effectiveness of SAT preparation classes. Also as seen in Table IV, there was a significant difference $(\mathrm{p}=.0009)$ in response between students who value the SAT and those who didn't when asked about the effectiveness of specific SAT information taught 
in general classes. Over half of the students who valued the SAT also agreed that SAT preparation classes and specific SAT information taught in general classes was effective.

\section{Question III}

Are students who regard the SAT as important more likely to perceive their teachers or administrators/ counselors as valuing the SAT than students who do not?

students. Items eight and nine on the scholastic Aptitude Preparation Survey for Students asked respondents to answer strongly agree, agree, don't know, disagree, or strongly disagree to the following: Administrators in my school value SAT scores; MY teachers value SAT scores. As seen in Figure 13, there was not a statistically significantdifference between those students who valued the SAT and those who did not in response to statement nine which stated that "MY teachers value SAT scores." Both groups generally concurred that about one third did not know if teachers valued the SAT and about half agreed that teachers valued the SAT. However, there was a statistically significant difference $(\mathrm{p}=.0029)$ in response between those who valued the SAT and those who did not in response to statement eight which stated "Administrators in my school value the SAT." Fifty-nine percent of those students who valued the SAT believed that their administrators also valued the SAT. Forty-three percent of those who did not value the SAT, did not know if their administrators value it or not. 
TABLE IV
DO TEACHERS, STUDENTS, OR COUNSELORS/ADMINISTRATORS WHO
VALUE THE SAT FOR STUDENTS PERCEIVE THAT SAT COMPUTER
PROGRAMS, SAT PREP CLASSES, OR SPECIFIC SAT
INFORMATION TAUGHT IN GENERAL CLASSES
IS MORE EFFECTIVE THAN THOSE WHO
DO NOT VALUE THE SAT?

\begin{tabular}{|c|c|c|c|}
\hline $\begin{array}{l}\text { SAT Computer } \\
\text { Progrems }\end{array}$ & $\begin{array}{l}X \text { Volue } \\
\text { the SAT }\end{array}$ & $\begin{array}{l}\text { * Do Not } \\
\text { Value the SAT }\end{array}$ & \\
\hline $\begin{array}{l}\text { Don't Know } \\
\text { Agree/Strongly Agree } \\
\text { Di sagree/Strongly Disagree }\end{array}$ & $\begin{array}{l}27.3 \\
16.3 \\
56.4\end{array}$ & $\begin{array}{r}25.0 \\
8.8 \\
66.2\end{array}$ & $\begin{array}{l}\text { Students } \\
\text { Not Significantly } \\
\text { Different }\end{array}$ \\
\hline $\begin{array}{l}\text { Don't Know } \\
\text { Agree/Strongly Agree } \\
\text { Disagree/Strongly Disagree }\end{array}$ & $\begin{array}{r}54.3 \\
38.1 \\
7.6\end{array}$ & $\begin{array}{r}65.1 \\
30.3 \\
4.7\end{array}$ & $\begin{array}{l}\text { Teachers } \\
\text { Not Significantly } \\
\text { Different }\end{array}$ \\
\hline $\begin{array}{l}\text { Don't Knoy } \\
\text { Agree/Strongly Agree } \\
\text { Disagree/Strongly Disagree }\end{array}$ & $\begin{array}{r}42.9 \\
53.6 \\
3.6\end{array}$ & $\begin{array}{r}9.1 \\
72.7 \\
0.0\end{array}$ & $\begin{array}{l}\frac{\text { Counselors/ }}{\text { Administrators }} \\
\text { Not Significantly } \\
\text { Different }\end{array}$ \\
\hline $\begin{array}{l}\text { SAT Preparation } \\
\text { Programs }\end{array}$ & $\begin{array}{l}* \text { Volue } \\
\text { the SAT }\end{array}$ & $\begin{array}{l}X \text { Do Not } \\
\text { Value the SAT }\end{array}$ & \\
\hline $\begin{array}{l}\text { Don't Know } \\
\text { Agree/Strongly Agree } \\
\text { Disagree/Strongly Disagree }\end{array}$ & $\begin{array}{l}20.9 \\
36.2 \\
43.2\end{array}$ & $\begin{array}{l}18.9 \\
23.0 \\
58.1\end{array}$ & $\begin{array}{l}\frac{\text { Students }}{\text { Significant }} \\
\text { Difference }(p=.0007)\end{array}$ \\
\hline $\begin{array}{l}\text { Don't Know } \\
\text { Agree/Strongly Agree } \\
\text { Disagree/Strongly Disagree }\end{array}$ & $\begin{array}{r}27.2 \\
67.4 \\
5.4\end{array}$ & $\begin{array}{r}25.6 \\
67.4 \\
7.0\end{array}$ & $\begin{array}{l}\text { Teachers } \\
\text { Not Significantly } \\
\text { Different }\end{array}$ \\
\hline $\begin{array}{l}\text { Don't Know } \\
\text { Agree/Strongly Agree } \\
\text { Disagree/Strongly Disagree }\end{array}$ & $\begin{array}{l}25.9 \\
62.9 \\
11.1\end{array}$ & $\begin{array}{r}9.1 \\
90.9 \\
0.0\end{array}$ & $\begin{array}{l}\text { Counselors } / \\
\frac{\text { Adninistrators }}{\text { Hot Significantly }} \\
\text { Different }\end{array}$ \\
\hline $\begin{array}{l}\text { Specific SAT Information } \\
\text { Taught in General Classes }\end{array}$ & $\begin{array}{l}X \text { Value } \\
\text { the SAT }\end{array}$ & $\begin{array}{l}X \text { Do Not } \\
\text { Value the SAT }\end{array}$ & \\
\hline $\begin{array}{l}\text { Don't Know } \\
\text { Agree/Strongly Agree } \\
\text { Disagree/Strongly Disagree }\end{array}$ & $\begin{array}{l}11.7 \\
52.4 \\
35.9\end{array}$ & $\begin{array}{l}13.2 \\
36.9 \\
49.9\end{array}$ & $\begin{array}{l}\frac{\text { Students }}{\text { Significant }} \\
\text { Difference }(\mathrm{Q}=.0009)\end{array}$ \\
\hline $\begin{array}{l}\text { Don't Know } \\
\text { Agree/Strongly Agree } \\
\text { Disagree/Strongly Disagree }\end{array}$ & $\begin{array}{r}6.5 \\
68.5 \\
25.0\end{array}$ & $\begin{array}{l}11.9 \\
57.1 \\
31.0\end{array}$ & $\begin{array}{l}\frac{\text { Teachers }}{\text { Hot Significantly }} \\
\text { Different }\end{array}$ \\
\hline $\begin{array}{l}\text { Don't Know } \\
\text { Agree/Strongly Agree } \\
\text { Disagree/Strongly Disagree }\end{array}$ & $\begin{array}{l}21.4 \\
64.3 \\
14.3\end{array}$ & $\begin{array}{r}9.1 \\
72.7 \\
18.2\end{array}$ & $\begin{array}{l}\frac{\text { Counselors/ }}{\text { Administrators }} \\
\text { Wot Significantly } \\
\text { Different }\end{array}$ \\
\hline
\end{tabular}


My Teachers Value SAT Scores
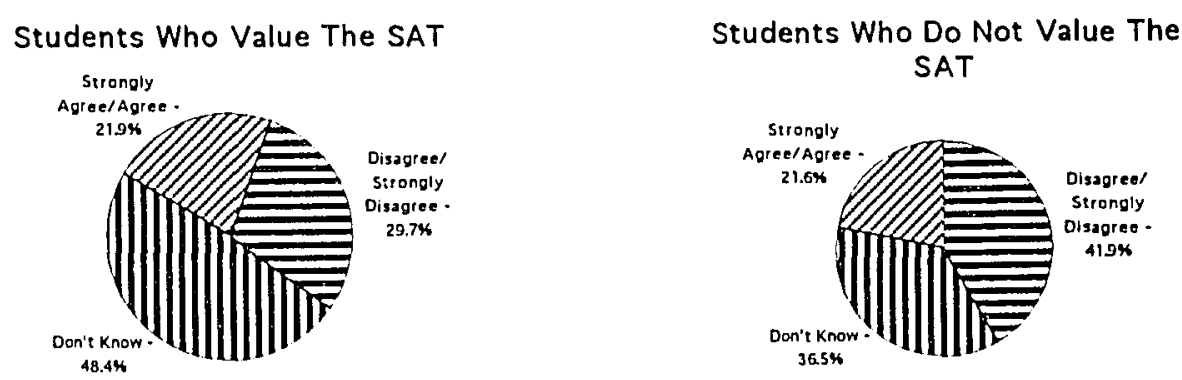

There was not a significant difference in responses.

My Administrators Value SAT Scores

Students Who Value The SAT

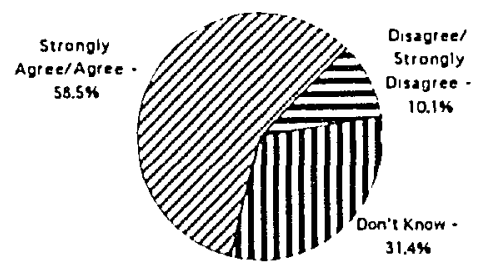

Students Who Do Not Value The SAT

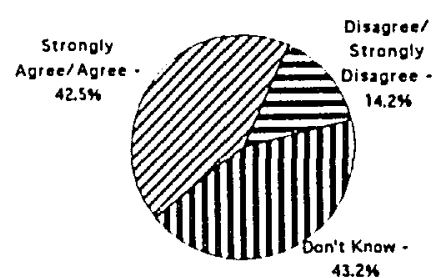

There was a significant difference $(p=.0(129)$ in responses.

Figure 13. Are students who regard the SAT as important more likely to perceive their teachers or administrators as valuing the SAT?

Teachers. Items eight and nine on the scholastic Aptitude Preparation Survey for Teachers asked respondents to answer strongly agree, agree, don't know, disagree, or strongly disagree to the following: My principal values SAT scores; I value SAT scores. As seen in Figure 14, there was not a statistical difference between teachers who valued SAT 
scores and those who did not in response to statement eight which stated administrators value the SAT. Over $70 \%$ of both groups agreed that administrators valued SATs, and about $20 \%$ of both groups did not know.

There was a statistically significant difference $(\mathrm{p}=.0013)$ in responses between teachers who valued SAT scores and those who did not in response to statement one which stated that SATs are important for students' future education. Of teachers who said they value SAT scores, $86 \%$ also said that SATs were important for students. of those who said that they did not value SAT scores, $29 \%$ said they disagreed that SATs were important for students.

\section{Counselors/Administrators. Items eight and nine on} the Scholastic Aptitude Preparation Survey for Counselors/ Administrators asked respondents to answer strongly agree, agree, don't know, disagree, or strongly disagree to the following: I value SAT scores; Teachers value SAT scores. As seen in Figure 15, there was not a statistically significant difference between counselors/administrators who valued the SAT and those who did not in response to statement one which states, "SATs are important to students for their future education." Over $70 \%$ of both groups agreed that SATs were important for students. There was a statistically significant difference $(\underline{\underline{p}}=.0058)$ between counselors/administrators who valued the SAT and those who did not in response to question 9: Teachers value the SAT. 
of those counselors/administrators who valued the SAT, $75 \%$ agreed that teachers valued the SAT. of those counselors/ administrators who did not value the SAT, $55 \%$ did not agree that teachers value the SAT.

\section{Principals Who Values SAT Scores}

Teachers Who Believe The SAT Is Important for Students

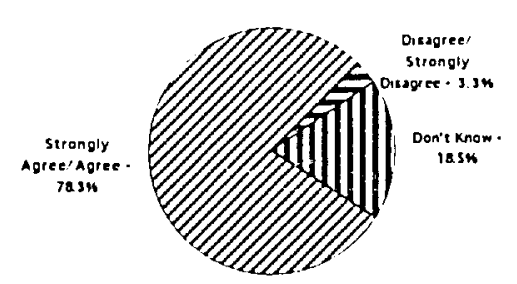

Teachers Who Do Not Believe The SAT Is Important for Students

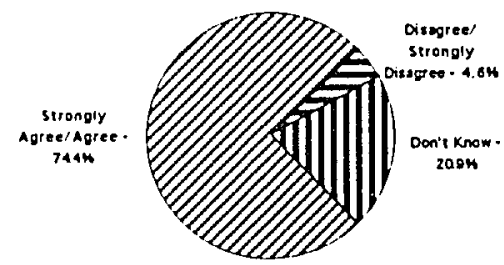

There were no significantly different responses.

Teachers Who Value SAT Scores

Teachers Who Believe The SAT Is

Important for Students

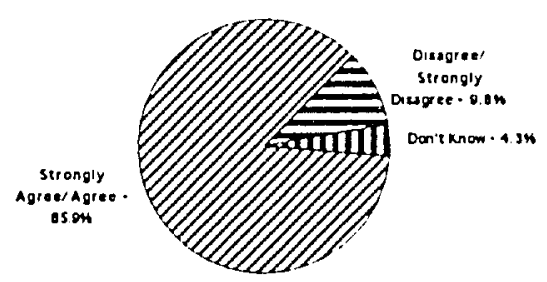

Teachers Who Do Not Believe The SAT Is Important for Students

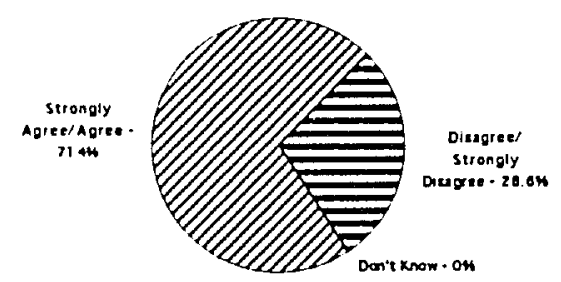

There was a significant difference $(p=.0013)$ in responses.

Figure 14. Do teachers perceive their administrators value the SAT and do the teachers themselves value the SAT? 
I Value SAT Scores

Counselors/Administrators Who Value The SAT

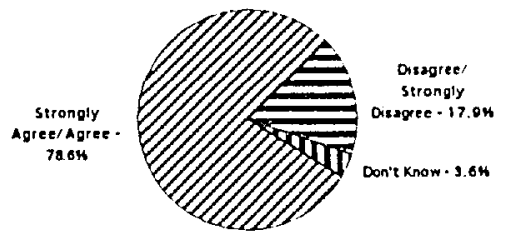

Counselors/Administrators Who Do Not Value The SAT

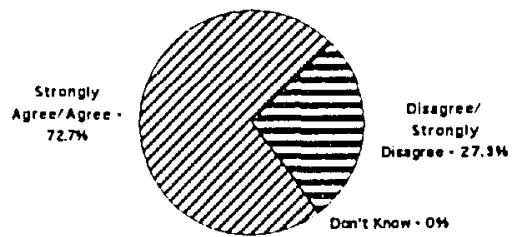

There was no significantly different responses.

My Teachers Value SAT Scores

Counselors/Administrators Who Value The SAT

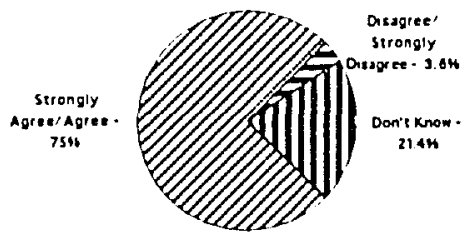

Counselors/Administrators Who Do Not Value The SAT

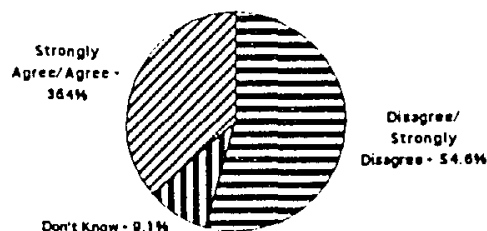

These was a significant difference $(\mathrm{p}=.0058)$ in responses.

Figure 15. Are counselors/administrators who regard the SAT as important more likely to perceive themselves or their teachers as valuing the SAT?

\section{Question IV}

Are students who perceive that their teachers or administrators regard the SAT as important more likely to perceive the preparation techniques effective than students who do not? 
There was a significant difference $(\underline{p}=.0000)$ in responses between students who agreed with item nine on the Scholastic Aptitude Test Preparation Survey: My teachers value SAT scores, and those who did not in regard to the effectiveness of specific SAT information taught in general classes. Of students who agreed or strongly agreed that their teachers valued SAT scores, $54 \%$ indicated that specific SAT information taught in general classes was a successful preparation technique. Only $36 \%$ of students who did not agree that their teachers valued SAT scores indicated that specific SAT information taught in general classes was a successful technique.

There was not a significant difference in responses between students who agreed that their teachers valued SAT scores and those who did not regarding the effectiveness of SAT computer preparation programs or SAT preparation classes.

There was a significant difference $(\underline{p}=.0008)$ in responses between students who agreed with item eight on the Scholastic Aptitude Preparation Survey: Administrators in my school value SAT scores, and those who did not in regard to the effectiveness of specific SAT information taught in general classes. Of students who agreed or strongly agreed that their administrators value SAT scores, $59 \%$ indicated that specific SAT information taught in general classes was an effective preparation technique. Only $37 \%$ of the 
students who did not agree that their administrators valued the SAT indicated that specific SAT information taught in general classes was a successful preparation technique.

There was a significant difference $(\underline{p}=.008)$ in response between those students who agreed that their administrators valued SAT scores and those who did not in regard to the effectiveness of SAT preparation classes. Of students who agreed that their administrators valued SAT scores, 598 indicated that SAT preparation classes were effective. of those who did not agree that their administrators valued SAT scores, only $37 \%$ indicated that SAT preparation classes were effective.

There was not a statistically significant difference in responses between students who agreed that their administrators valued SAT scores and those who did not in response to the effectiveness of SAT computer programs. 


\section{CHAPTER V}

SUMMARY, CONCLUSIONS, AND RECOMMENDATIONS

\section{SUMMARY}

This study was designed to investigate the perceptions of students, teachers, counselors, and administrators about the effectiveness of three SAT preparation techniques. Understanding the SAT preparation techniques students perceive to be effective is valuable counseling information for helping students perform to their highest potential on the SAT.

The findings of this study reveal that groups of students and teachers perceived specific SAT information taught in general classes to be an effective preparation technique. Students perceived that specific SAT information taught in their classes helped them be more prepared for the SAT. They also perceived that their teachers gave tests which required the higher level thinking skills of analyzing, synthesizing, and evaluating. These findings were supported by perception and self-efficacy theories from Craig (1976) and Bandura (1986). Craig purports that every individual's thoughts of what helped him/her to perform well on the SAT is exclusive to that individual's perception. 
With Bandura's theory in mind, it is reasonable to assume that a specific SAT preparation technique may develop the ability to demonstrate learning more strongly if the individual has a strong perception that the preparation technique will help him/her perform better on the SAT. According to Cameron (1989), the individual's perception is independent of the reported effectiveness of the SAT preparation technique. It is the perception of preparation and improved skills of knowledge that ensure optimal use of individual knowledge during testing.

The questionnaire was completed by students, teachers, counselors, and administrators. Six hundred thirty-one students, 133 teachers, and 37 counselors/administrators from 10 target high schools in the Portland metropolitan area were administered the questionnaire. students, teachers, counselors, and administrators were selected as described under "Sample Design" in Chapter III.

\section{CONCLUSIONS}

\section{Question I}

What is the perceived effectiveness of three SAT preparation techniques: SAT computer programs, SAT preparation classes, and specific SAT information taught in general classes among students, teachers, and counselors/ administrators? 
Results of the statistical study reveal that the perceived effectiveness of three SAT preparation techniques was significantly different $(\underline{p}=.0000)$ among student, teacher, and counselor/administrator groups for each of the three preparation techniques. The following are conclusions which can be drawn from the responses to Question I. Because of the difference in the perceived effectiveness of the three preparation techniques among students, teachers, and counselors/administrators, it can be concluded that even though teachers and counselors/ administrators believe that some or all of the preparation techniques are effective, students do not perceive them to be as helpful.

Because of the difference in the perceived effectiveness of the SAT preparation techniques among the specific groups of teachers, it can be concluded that if a teacher has had PSAT/SAT training the teacher is more likely to believe that specific SAT information taught in general classes is an effective SAT preparation technique. Teachers who taught college level classes or who had higher level thinking skills training were not more likely to perceive effective SAT computer programs, SAT preparation classes, or specific SAT information taught in general classes.

Because of the difference in the perceived effectiveness of the SAT preparation techniques among three specific groups of students, it can be concluded that if a 
student is enrolled in college prep/advanced classes, has taken or plans to take the SAT, or plans to go to a four year college, the student is more likely to believe that specific SAT information taught in general education classes is effective.

\section{Question II}

Are students who regard the SAT as important more likely to know about, use, and perceive effective the three preparation techniques than students who do not?

Results of the study reveal that students who regard the SAT as important are not more likely to know about or use, SAT computer preparation courses or SAT preparation classes than students who do not regard the SAT as important. Students who value the SAT also are not more likely to perceive effective SAT computer preparation courses than those who do not value the SAT. However, those who do regard the SAT as important do know about, use, and perceive specific SAT information taught in general classes as more effective than those who do not regard the SAT as important. They also perceive SAT preparation classes as more effective than those students who do not value the SAT. Also, because of the difference in the perceived availability and use of the three preparation techniques among students, teachers, counselors/administrators, it can be concluded that the preparation techniques are available, but that the majority of students do not use them, the 
majority of teachers do not know whether or not students use them, and the majority of counselors/administrators think they do use them.

\section{Question III}

Are students who regard the SAT as important more likely to perceive their teachers or administrators as valuing the SAT than students who do not?

study findings demonstrate that students who value the SAT are not more likely to perceive that their teachers value the SAT than those students who do not value the SAT. However, students who value the SAT are more likely to perceive that their administrators value the SAT than those students who do not.

\section{Question IV}

Are students who perceive that their teachers or administrators regard the SAT as important more likely to perceive the preparation techniques effective than students who do not?

The analysis reveals that students who perceive that their teachers value the SAT are not more likely to perceive that SAT computer classes or SAT preparation classes are effective than students who do not value the SAT. They are more likely, however, to perceive that specific SAT information taught in general classes is an effective preparation technique. Students who perceive that their 
administrators value the SAT are more likely to perceive that SAT preparation classes, and specific SAT information taught in general classes is an effective SAT preparation technique.

This study showed that although the majority of students did not perceive any of the preparation techniques to be effective, some specific groups of students did. Students who valued the SAT, who were enrolled in a college prep/advanced level class, who had taken or planned to take the SAT, and who planned to go to a four year college all agreed that teaching specific SAT information in general classes was an effective preparation technique. They agreed (survey question 10) that there had been specific information given in classes that helped them be better prepared for the SAT. They also agreed (survey question 12) that teachers gave tests which required them to analyze, synthesize, and evaluate. In other words, students who perceived that the SAT was somehow connected with their future believed integration of SAT information in general classes made them feel most prepared for the SAT. These findings are supported by Bandura's (1986) theory that when students have strong self-beliefs about knowing information, they will demonstrate their knowledge better. student perceptions relative to SAT information taught in general classes supports this study's assumption that preparation may develop the ability to demonstrate learning and/or the 
self-beliefs that ensure optimal use of learning throughout the SAT.

Teachers who had PSAT/SAT training also believed that the training was effective. Cox and Robinson (1988, pp. 22-23) supported this finding through their discussion of specific methods to integrate preparation techniques into the general classroom in Anaheim, California. Therefore, it would be appropriate to suggest that this preparation technique could be enhanced by integrating specific SAT information into the curriculum of general classes for both the mathematics and the verbal components of the SAT such as was done in Anaheim.

Cox and Robinson (1988, pp. 22-23) advocated that integration should include a belief system for consumers of the SAT, which would support the perception that the SAT measures valuable, worthwhile skills, basic critical thinking skills, vocabulary use and analysis, and comprehensive reading skills. Also it should be understood that raising SAT scores in the absence of improving the quality of the educational programs that produce them is a shallow goal. A more appropriate goal is one of enhancing the quality of curricular programs through integrating SAT content with the existing curriculum over a lengthy period of time making skill development the goal. Johnson and Wallace's (1989) study suggested that review of algebraic functions/procedures and test taking strategies for 
approaching those and other types of problems faced on the SAT as helpful in assisting students with somewhat deficient quantitative backgrounds in applying that knowledge effectively within the testing situation. Using this approach, the curriculum is not disrupted but, rather, improved by integrating one with the other.

students, teachers, and counselors/administrators agreed that SAT computer programs and SAT preparation classes were available. Teachers and counselors/ administrators either didn't know or perceived that students used computer programs and participated in preparation classes. Students said they neither used SAT computer programs nor did they participate in SAT preparation classes. There was an obvious lack of awareness and/or communication about these two preparation techniques. A strong program of communication and awareness should be implemented such as the one that McGee and Rose (1982, p. 62) which included a "Support strategies" component. The awareness strategies should be focused on training for all teachers in understanding the content, format, and scoring of the SAT. The communication strategies should include annual staff meeting presentations which present current SAT preparation techniques, descriptions, and results. Current analyses of the curriculum taken by high SAT scoring students should be presented to curriculum planners for SAT 
preparation, and to all teachers for better understanding of what is actually taught and why.

Both students and teachers who perceived the SAT to be important for student's future education, agreed that their administrators valued the SAT. Administrators should insure that their staff and students understand that testing well is congruent with curriculum integration of SAT information. It is important that administrators provide leadership to staff and students that creates a sense of purpose and ownership for integrating preparation techniques within the curriculum. Teachers need a formal opportunity to agree or disagree philosophically with what is being proposed. In addition, they need a well-defined context within which to operate and then the freedom to choose from within that context.

\section{RECOMMENDATIONS FOR FUTURE RESEARCH}

An avenue for future research in SAT test preparation would be a study comparing several years of students who have SAT scores to discover their perceptions of effective SAT preparation techniques within the general curriculum, and how those techniques might be improved to increase student learning and therefore, SAT testing ability. It would be of interest to curriculum and instructional planners to know which SAT preparation techniques within the curriculum are consistently perceived effective by students 
who scored well on the SAT. A study of the perceptions of effective preparation techniques within the curxiculum from high scoring students should be conducted across an entire district, several districts, state or nation-wide, generating a much larger sample and thereby providing more powerful statements about effective integrated SAT preparation techniques.

Exploration of issues raised by this study would provide many areas for new and related research. Examples of additional research questions should include:

1. How does one integrate specific SAT information into the curriculum of general classes in both mathematical and verbal skill areas to insure minorities and women score at their highest capability?

2. What are perceived as the optimal grade levels (junior high, tenth, eleventh, or twelfth grade) for SAT curriculum integration?

3. Which instructional techniques (cooperative learning, applied academics, or direct instruction) are perceived optimal to teach SAT information within general classes?

4. Which higher level thinking skill (analyzing, synthesizing, or evaluating) instructional activities successfully teach SAT concepts? 
5. What is the relationship between the availability of SAT preparation techniques and students' perceptions of effectiveness?

Research questions could be developed to provide more information regarding perceptions of how administrators should provide leadership to instructional staff and students to create an optimal sense of purpose and ownership for teaching/learning SAT information in general classes. However, the larger issues that further research could illuminate have to do with teaching self-efficacy and the reasoning and analyzing tools with which to effect whatever future assessment situation might arise. This study of the perceptions of effectiveness of SAT preparation techniques is only a small area in the field of assessment where self-efficacy and higher level thinking skills instruction could strengthen the abilities of students to test optimally through curriculum integration. As Bandura (1986) suggested, the greatest benefits learning can bestow are reasoning and analyzing tools with which to effect solutions on one's own. student perceptions of how best to integrate self-efficacy with higher level thinking skills are studies which deserve more research and analysis specific to the assessment areas of verbal and mathematics. 
REFERENCES

Abella, R. (1992, Summer). Achievement tests in elementary English-for-speakers-of-other-languages (ESOL) exit criteria: And evaluation. Educational evaluation and policy analysis, 14 (2), 169-174.

Aikens, L. A., \& Phillips, B. (1989, November). Should SATs be eliminated? News Today, 8 (4) 35 .

Alderman, D. I., \& Powers, D. E. (1980, Summer). The effects of special preparation on SAT-verbal scores. American Educational Research Journal, 17 (2), 239-51.

Angoff, W. H. (1971). The college board admissions testing program: A technical report on research and development activities relating to the scholastic aptitude test and achievement tests. Princeton, NJ: College Entrance Examination Board.

Bandura, A. (1977, Autumn). Self-efficacy toward a unifying theory of behavioral change. Psychological Review, 84, 191-215.

Bandura, A. (1986). Social foundations of thought and action. Englecliffs, NJ: Prentice-Hall.

Best, J. W. (1977) . Research in education. Princeton, NJ: Prentice-Hall.

Bishop, J. (1989, March). Is the test score decline responsible for the productivity growth decline? American Economic Review, $\underline{79}$ (1), 178.

Bond, L. (1986, November). In defense of admissions testing. Education Digest, 52, 40-42.

Borg, W. (1987). Applying practical research. New York: Longman, Inc.

Borg, W., \& Gall, M. (1989). Educational research. New York: Longman, Inc.

Buzzel, C. H. (1990, May). State-of-the-art curricula. The Vocational Educational Journal, 65 (4), 10 . 
Caffin, G. C. (1988, october). Computers can help students improve SAT scores. NASSP Bulletin, 72, 78-83.

Cameron, R. G. (1989). The common yardstick: A case for the SAT. New York: The College Entrance Examination Board.

Chance, P. (1988, May). Testing education: An attack on the scholastic aptitude test unwittingly reveals the failure of American schools. Psychology Today, 22, 20 .

College Entrance Examination Board. (1970). Report of the commission on tests II briefs. New York: Author.

College Entrance Examination Board. (1977). National report: College-bound seniors. New York: Author.

College Entrance Examination Board. (1980). The undergraduate admissions: The realities of institutional policies, practices, and procedures. New York: Author.

College Entrance Examination Board. (1988). Guide to the admissions testing program 1987-88. Princeton, NJ: Author.

College Entrance Examination Board. (1989a). The college Handbook, 1988-89. Princeton, NJ: Author.

College Entrance Examination Board. (1989b). National college bound seniors, 1988-89. New York: Author.

College Entrance Examination Board. (1989c). Taking the SAT: A quide to the scholastic aptitude test and the test of standard written English. New York: Author.

Conlon, G. (1987). Reading better will help you prepare for the SAT. Princeton, NJ: College Entrance Examination Board.

Cox, J., \& Robinson, K. (1988). A school district tackles SAT preparation. Princeton, NJ: College Entrance Examination Board.

Craig, G. J. (1976). Human development. Englecliffs, NJ: Prentice-Hall, Inc.

Crouse, J. (1986a, January). Should a million and a half students be required to take the SAT next year? Phi Delta Kappan, 67, 346-356. 
Crouse, J. (1986b, February 26). The time has come to replace the SAT. Chronicle of Higher Education, 31, 40.

Crouse, J., \& Trusheim, D. (1989, April). Five challenges for the Scholastic Aptitude Test. Education Digest, 54, 26-28.

Dersimonian, R., \& Laird, N. M. (1983, February). Evaluating the effect of coaching on SAT scores: A meta-analysis. Harvard Educational Review, 53 (1), $1-15$.

Dodge, S. (1989, September 20). SAT, ACT scores remain steady or drop slightly: students from minority groups continue to show improvement. The Chronicle of Higher Education, 36 (3), 36-37.

Dyer, H. S. (1987, February). The effects of coaching for scholastic aptitude. NASSP Bulletin, 71, 46-50, 52-53.

Echternacht, G. J. (1977). A comparative study of secondary schools with different score patterns. Princeton, NJ: Educational Testing Service.

Educational Testing Services. (1989). ETS 1989 annual report. Princeton, NJ: Author.

Ellman, N. (1988, February). The impact of competency testing on curriculum and instruction. NASSP Bulletin, 72, 49 .

Evangelauf, J. (1989, February 15). Critics and defenders of admission tests eye court's limit on use. The Chronicle of Higher Education, 35 (23), 1 .

Flynn, J. R. (1988, June). The decline and rise of scholastic aptitude scores. The American Psychologist, 43,479 .

Fuess, C. M. (1967). The college board its first fifty years. New York: College Entrance Examination Board.

Gabriel, G. T. (1987). Involving more students in the PSAT/NMSOT makes sense. NeW York: The College Board News.

Garvey, J. E. (1981). Testing for college admissions: Trends and issues. Arlington, VA: Educational Resource Service, Inc. 
Gurman, E. B. (1989, May). The effect of prior test exposure on performance in two instructional settings. The Journal of Psychology, 123 (3), 275.

Hodgkinson, H. L. (1982, December). What's still right with education. Phi Delta Kappan, 64, 231-235.

Hopmeier, G. (1984). SAT scores improve 94 points. Electronic Education, 4 (1), 13-14.

Howe, H. (1985, May). Let's have another SAT score decline. Phi Delta Kappan, 66, 599-602.

Howe, H. (1986, January). What failing SAT's really mean. Education Digest, 51, 18-21.

Izarek, S. (1989, February 14). Computer study guide offers help in making the grade on the SAT. PC Magazine, 8, pp. 436 .

Johnson, S. T., \& Wallace, M. B. (1989, Summer). Characteristics of SAT quantitative items showing improvement after coaching among black students from low-income families: An exploratory study. Journal of Educational Measurement, 26 (2), 133-145.

Kulich, J. (1984, October). Synthesis of research on effects of accelerated instruction. Educational Leadership, 42 , 84-89

Kulik, J. (1984, Fall). Effects of practice on aptitude and achievement test scores. American Educational Research Journal, $\underline{54}$ 409-425.

Laflamme, J. (1988, Spring). SAT preparation: one teacher's results. Princeton, NJ: College Entrance Examination Board.

Madaus, G. F. (1985, May). Test scores as administrative mechanisms in educational policy. Phi Delta Kappan, 66, 611-617.

Magner, D. K. (1988, October 5). High-school students spend little money and time to prepare for SAT, study finds. The Chronicle of Higher Education, 35, A39.

Malamud, M. (1984, September 18). New help in the SAT grind. PC Magazine, $\underline{3}$, pp. 66 .

Malamud, M. (1985, June 11). Study SAT programs. PC Magazine, 4, pp. 289. 
McGee, J. C. , \& Rose, J. S. (1982, November). Improving test scores: Focus on the SAT. NASSP Bulletin, 66, 59-62.

Messick, S. (1982, summer). Issues and equity in the coaching controversy: Implications for educational testing and practice. Educational Psychologist, 17, 67-91.

Morgan, R. (1989). An examination of the relationship of academic course work with admissions test performance (Report 86). New York: The College Entrance Examination Board.

Morrison, w. (1961). The school record its use and abuse in college admissions. New York: College Entrance Examination Board.

Mullins, C. J., \& Mullins, N. C. (1984, November). Scoring on the SAT: Ten programs to help students achieve maximum scores on the college-board exams. New York: College Entrance Examination Board.

A multiple choice of SAT cram courses. (1989, February 27). U.S. News and World Report, 106, pp. 65, 66, 68 .

O'Rourke, B. (1986, November). The danger of standardized test-driven school reform. The clearing House, $\underline{60}$, 135-136.

Owen, D. (1983, May). 1983: The last days of ETS. Harper's Magazine, 266, p. 21.

Owen, D. (1984, August). SAT coaching guides: Do they work? The Washington Post Education Review, A3.

Owen, D. (1985, April) How they write the SAT. Washington Monthly, 17, 48 .

Potter, P. B., \& Dawson, J. (1988, October). National merit scholars by design, not by chance. Educational Leadership, 46, 54-56.

Powers, D. E. (1988). Preparing for the SAT: A survey of programs and resources. New York: The college Board Report.

Powers, D. E., \& Alderman, D. L. (1979) The use, acceptance, and impact of taking the SAT: A test familiarization booklet. Princeton, NJ: Education Testing Service. 
Powers, D. E., \& Alderman, D. L. (1983, Spring). Effects of test familiarization on SAT performance. Journal of Educational Measurement, 20 (1), 71-79.

Putka, G. (1987, September 12). Scores on college entrance tests fall, adding to concern about U.S. schools. The Wall street Journal, p. Alo.

Rawl, E. H. (1984, January). Test-taking strategies can be the key to improving test scores. NASSP Bulletin, 68, 108-112.

A rejection slip for the SAT. (1987, April 27) Newsweek, 109, pp. 71 .

The reign of ETS: The corporation that makes up minds. $(1980)$. Washington, DC: The Learning Research Project.

Response Analysis Corporation. (1978). SAT monitor program: High school students view the SAT and college admission process. Princeton, NJ: Educational Testing Service.

Rosser, P. (1988, January). Girls, boys, and the SAT: Can we even the score? NEA Today, 6,48 .

Salganik, L. H. (1985, May). Why testing reforms are so popular and how they are changing education. Phi Delta Kappan, 66, 607-610.

Sanasohn, D. (1986, September 24). SAT significance: None of the above. The Oregonian, pp. B4, C2.

Sanoff, A. P. (1989, January 30). When is the playing field too level? U.S. News and World Report, 106, pp. 68 .

The SAT pill. (1987, November 16). Newsweek, 110, pp. 103.

SAT scores rise for first time in 19 years. (1982, September 22). Education Daily, 1-3.

SAT's school by school. (1987, October 26). U.S. News and World Report, 103, pp. 90 .

Schaag, P. (1986, October 4). Why Johnny can't.... : What the test scores really mean (part 1). The Nation, $\underline{243}, 297$. 
Schrader, W. B. (1976). Distribution of SAT scores to colleges as an indicator of changes in the SAT candidate population. Princeton, NJ: College Entrance Examination Board.

Seligman, D. (1.988, December 5). Being braver than George Plimpton, laying Pollyana in the state Department, and other matters. Fortune, pp. 118, 229.

Shannon, L. R. (1988, September 13). SAT guide on disk. The New York Times, pp. 137.

Sinka, D. K. (1986, September/October). Relationship requirements and course offerings to scholastic Aptitude Test performance of seniors in high school. Journal of Educational Research, 80 (1), 5-9.

Smaller families reason for test score rise, researcher claims. (1986, July 18). Education Daily, p. 5.

stanley, J. W. (1977). The predictive value of the SAT for brilliant seventh and eighth graders. Princeton, NJ: College Entrance Examination Board.

Steelman, I. C., \& Powell, B. (1984, November). Violations in state SAT performance: Meaningful or misleading? Harvard Education Review, 54, 389-412.

Steelman, L. C., \& Powell, B. (1985, May). Appraising the implications of the SAT for educational policy. Phi Delta Kappan, 61, 603-607.

Sternglass, E. J., \& Bell, S. (1983, April). Fallout and SAT scores: Evidence for cognitive damage during early infancy. Phi Delta Kappan, 64, 539-545.

Stickney, J. (1984, January). Aceing the SATs. Money, 13, 121.

Study links skill levels, hormones. (1988, November 17). The Daily News, p. A6.

Thomson, S. (1978). Guidelines for improving SAT scores. Reston, VA: NASSP.

Tooley, J. (1988, October 3). Testing the college-bound. U.S. News and World Report, 105 , pp. 71 .

Valentine, J. A. (1987, Spring). The college board and school curriculum. The college Board Review, 143, 38-41. 
Vital statistics: Average SAT scores by years of study in six academic subjects. (1989, Fall). College Board Review, 153, 52 .

Whitla, D. K. (1988, Summer) , Coaching: Does it pay? Not for Harvard students. The College Board Review, 148, $32-35$.

Wilder, R. (1989, February 27). A multiple choice of SAT cram courses. U.S. News and World Report, 106, pp. 65.

Wirtz, w. (1977). On further examination. Princeton, NJ: College Entrance Examination Board.

Yardley, J. (1987, September 7). Education bureaucraticization damned in another report. The oregonian, pp. B4, B5. 
APPENDIX A

THE SCHOLASTIC APTITUDE PREPARATION SURVEYS 
STUDENT SURVEY

1. Scholastic Aptitude Tests (SAT) are important to me for my future education.
0
1
2
3
4

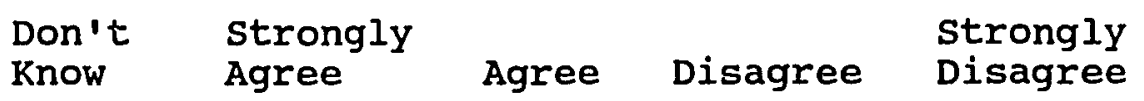

2. Computer programs are available to help prepare me to the SAT.
0
1
2
3
4

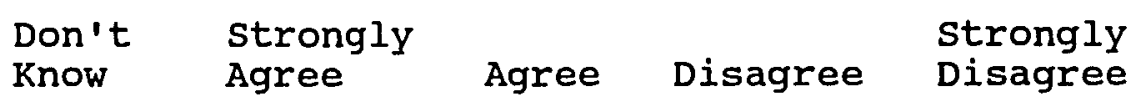

3. I've completed one of these computer programs.

$\begin{array}{lllll}0 & 1 & 2 & 3 & 4\end{array}$

\begin{tabular}{|c|}
\hline $\begin{array}{l}\text { Don't } \\
\text { Know }\end{array}$ \\
\hline
\end{tabular}

4. I'm better prepared for the SAT because I've completed one of these programs.
0
1
2
3
4

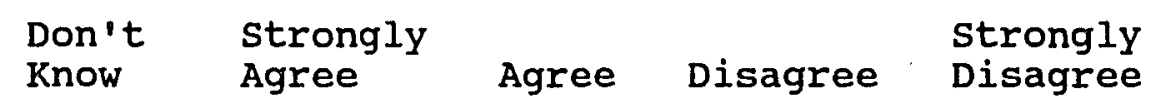

5. SAT preparation (workshops, classes, etc.) are offered at my school.

$\begin{array}{lllll}0 & 1 & 2 & 3 & 4\end{array}$
Don't
strongly

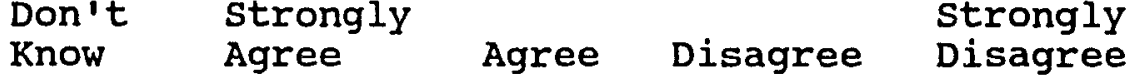
Strongly

6. I've participated in this SAT preparation.
0
1
2
3
4

Don't strongly

Know

Agree

Agree Disagree

strongly

Disagree 
7. The SAT class has helped me feel more confident about taking the SAT.

$\begin{array}{lllll}0 & 1 & 2 & 3 & 4\end{array}$

$\begin{array}{llll}\text { Don't } & \text { Strongly } & & \text { Strongly } \\ \text { Know } & \text { Agree } & \text { Agree } & \text { Disagree } \\ \text { Disagree }\end{array}$

8. Administrators in my school value SAT scores.
0
1
2
3
4

\begin{tabular}{|c|c|c|c|}
\hline $\begin{array}{l}\text { Don't } \\
\text { Know }\end{array}$ & $\begin{array}{l}\text { Strongly } \\
\text { Agree }\end{array}$ & Agree & Disagree \\
\hline
\end{tabular}

9. My teachers value SAT scores.

0

1

2

3

4

$\begin{array}{llll}\text { Don't } & \text { Strongly } & & \text { Strongly } \\ \text { Know } & \text { Agree } & \text { Agree } & \text { Disagree } \\ \text { Disagree }\end{array}$

10. There has been specific information in my classes that has helped me be better prepared for the SAT.
0
1
2
3
4

$\begin{array}{llll}\text { Don't } & \text { Strongly } & & \text { Strongly } \\ \text { Know } & \text { Agree } & \text { Agree } & \text { Disagree } \\ \text { Disagree }\end{array}$

11. Teachers in my classes mention that specific topics will be present on the SAT.
0
1
2
3
4

Don't strongly

Know Agree

Agree Disagree

strongly

Disagree

12. Sometimes my teachers give tests which require me to analyze, synthesize, and evaluate.

0

Don't strongly

Know
1

Agree
2

3

4

Strongly

Disagree 
13. I'm enrolled in college preparation or advanced placement classes.

$\begin{array}{lllll}0 & 1 & 2 & 3 & 4\end{array}$

$\begin{array}{llll}\text { Don't } & \text { Strongly } & & \text { strongly } \\ \text { Know } & \text { Agree } & \text { Agree Disagree } & \text { Disagree }\end{array}$

14. I have taken or I plan to take the Scholastic Aptitude Test.

$\begin{array}{ccccc}0 & 1 & 2 & 3 & 4 \\ \begin{array}{l}\text { Don't } \\ \text { Know }\end{array} & \begin{array}{l}\text { Strongly } \\ \text { Agree }\end{array} & \text { Agree } & \text { Disagree } & \begin{array}{l}\text { Strongly } \\ \text { Disagree }\end{array}\end{array}$

15. I plan to attend a four year college.

0

1

2

3

4

$\begin{array}{llll}\text { Don't } & \text { Strongly } & & \text { Strongly } \\ \text { Know } & \text { Agree } & \text { Agree Disagree } & \text { Disagree }\end{array}$ 
1. Scholastic Aptitude Tests (SAT) are important to students for their future education.

0

1

Don't strongly
2

Agree Disagree
3

4

strongly

Disagree

2. Computer programs are available for students to help prepare them for the SAT.

0

Don't Know
1

strongly Agree
2

3

4

Strongly

Disagree

3. Students are using these computer programs.

0

1

Don't strongly

Know Agree
2

Agree Disagree strongly

Disagree

4. Students are better prepared for the SAT because they have completed these computer programs.

0

Don't

Know
1

strongly Agree
2

3

Agree Disagree
Strongly

Disagree

5. SAT preparation (workshops, classes, etc.) are offered at my school.

0

1

2

3

4

$\begin{array}{ll}\text { Don't } & \text { strongly } \\ \text { Know } & \text { Agree }\end{array}$

Agree Disagree

Strongly

Disagree

6. Students have or are participating in this SAT preparation.

0

Don't know
1

strongly Agree
2

3

4

strongly

Disagree 
7. Students are better prepared for the SAT because they have taken an SAT class.

0

1

2

3

4

Don't strongly

Know

Agree

Agree Disagree

Strongly

Disagree

8. MY principal values SAT scores.

0

Don't Strongly

Know Agree
2

Agree Disagree
Strongly

Disagree

9. I value SAT scores.

0

Don't
1

Strongly Agree
2

Agree Disagree
3

4

Strongly

Disagree

10. I provide specific information in my classes which will help my students be better prepared for the SATO.
0
1
2
3
4

$\begin{array}{llll}\text { Don't } & \text { Strongly } & & \text { Strongly } \\ \text { Know } & \text { Agree } & \text { Agree } & \text { Disagree } \\ \text { Disagree }\end{array}$

11. I specifically state to my students that certain topics will be present on the SAT.

$\begin{array}{lllll}0 & 1 & 2 & 3 & 4\end{array}$

$\begin{array}{llll}\text { Don't } & \text { Strongly } & & \text { Strongly } \\ \text { Know } & \text { Agree } & \text { Agree } & \text { Disagree } \\ \text { Disagree }\end{array}$

12. I sometimes give tests which require my students to analyze, synthesize, and evaluate.

0

Don't strongly

Know
1

Agree
2

3

4

Strongly

Agree Disagree Disagree 
13. I teach college level and/or advanced placement classes.

$\begin{array}{ccccc}0 & 1 & 2 & 3 & 4 \\ \begin{array}{l}\text { Don't } \\ \text { Know }\end{array} & \begin{array}{l}\text { Strongly } \\ \text { Agree }\end{array} & \text { Agree } & \text { Disagree } & \begin{array}{l}\text { Strongly } \\ \text { Disagree }\end{array}\end{array}$

14. I have received higher level thinking skills training.

$\begin{array}{ccccc}0 & 1 & 2 & 3 & 4 \\ \text { Don't } & \begin{array}{l}\text { Strongly } \\ \text { Know }\end{array} & \text { Agree } & \text { Agree } & \text { Disagree }\end{array}$

15. I have received PSAT/SAT training.

0

Don't
1

Strongly

Agree
2

Agree
3

Strongly

Disagree 
COUNSELOR/ADMINISTRATOR SURVEY

1. Scholastic Aptitude Tests (SAT) are important to students for their future education.

$\begin{array}{lllll}0 & 1 & 2 & 3 & 4\end{array}$

$\begin{array}{llll}\text { Don't } & \text { Strongly } & & \text { Strongly } \\ \text { Know } & \text { Agree } & \text { Agree } & \text { Disagree } \\ \text { Disagree }\end{array}$

2. Computer programs are available for students to help prepare them for the SAT.

$\begin{array}{lllll}0 & 1 & 2 & 3 & 4\end{array}$

$\begin{array}{llll}\text { Don't } & \text { Strongly } & & \text { Strongly } \\ \text { Know } & \text { Agree } & \text { Agree } & \text { Disagree } \\ \text { Disagree }\end{array}$

3. Students have or are using these computer programs.

$\begin{array}{lllll}0 & 1 & 2 & 3 & 4\end{array}$

$\begin{array}{llll}\text { Don't } & \text { strongly } & & \text { Strongly } \\ \text { Know } & \text { Agree } & \text { Agree } & \text { Disagree } \\ \text { Disagree }\end{array}$

4. Students are better prepared for the SAT because they have completed these computer programs.

$\begin{array}{lllll}0 & 1 & 2 & 3 & 4\end{array}$

$\begin{array}{llll}\text { Don't } & \text { Strongly } & & \text { Strongly } \\ \text { Know } & \text { Agree } & \text { Agree Disagree } & \text { Disagree }\end{array}$

5. SAT preparation (workshops, classes, etc.) are offered at my school.

$\begin{array}{lllll}0 & 1 & 2 & 3 & 4\end{array}$

$\begin{array}{llll}\text { Don't } & \text { Strongly } & & \text { Strongly } \\ \text { Know } & \text { Agree } & \text { Agree } & \text { Disagree } \\ \text { Disagree }\end{array}$

6. Students have or are participating in this SAT preparation.

0

1

2

3

4

Don't strongly

Know Agree

Agree Disagree $\begin{aligned} & \text { Strongly } \\ & \text { Disagree }\end{aligned}$ 
7. Students are better prepared for the SAT because they have taken this SAT preparation.

0

$\begin{array}{ll}\text { Don't } & \text { Strongly } \\ \text { Know } & \text { Agree }\end{array}$

Know

1

2

3

4

Agree Disagree $\begin{aligned} & \text { Strongly } \\ & \text { Disagree }\end{aligned}$

8. I value SAT scores.

$\begin{array}{lllll}0 & 1 & 2 & 3 & 4\end{array}$

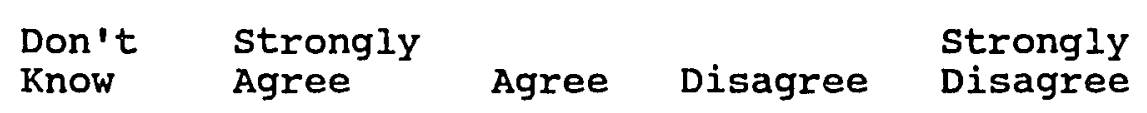

9. Teachers value SAT scores.

0

1

2

3

4

Don't strongly

Know Agree

Agree Disagree

Strongly

Disagree

10. Teachers provide specific information in their classes which help students be better prepared for the SAT.
0
1
2
3
4

Don't strongly

Know

Agree

Agree

Disagree

Strongly

Disagree

11. Teachers specifically state to students that certain topics will be present on the SAT.

0

$$
\begin{array}{ll}
\text { Don't } & \text { Strongly } \\
\text { Know } & \text { Agree }
\end{array}
$$

2

3

4

Strongly

Disagree

12. Teachers sometimes give tests which require students to analyze, synthesize, and evaluate.

0

Don't know
1

Strongly Agree
2

3

4

Strongly

Agree Disagree

Disagree 
13. College level and/or advanced placement classes are offered at my school.

$\begin{array}{lllll}0 & 1 & 2 & 3 & 4\end{array}$

$\begin{array}{llll}\text { Don't } & \text { Strongly } & & \text { Strongly } \\ \text { Know } & \text { Agree } & \text { Agree } & \text { Disagree } \\ \text { Disagree }\end{array}$

14. Higher level thinking skills training has been offered to teachers at my school.
0
1
2
3
4

Don't strongly

Know Agree

Agree Disagree Disagree

15. Students are counseled before taking the PSAT and/or the SAT.

0

1

2

3

4

Don't strongly

know

Agree

Agree

Disagree

Strongly

Disagree 
APPENDIX B

TEST PREPARATION SUPPORTING DATA 
PERCEIVED EFFECTIVENESS OF IDENTIFIED

SAT PREPARATION TECHNIQUES--

STUDENTS

\begin{tabular}{lccc}
\hline & $\begin{array}{c}\text { SAT } \\
\text { Computer } \\
\text { Programs }\end{array}$ & $\begin{array}{c}\text { SAT } \\
\text { Preparation } \\
\text { Classes }\end{array}$ & $\begin{array}{c}\text { Specific SAT } \\
\text { Information } \\
\text { Taught in } \\
\text { General Classes }\end{array}$ \\
\hline Don't Know & 27.9 & 22.5 & 15.5 \\
Strongly Agree & 3.9 & 10.1 & 14.4 \\
Agree & 10.3 & 20.9 & 30.2 \\
Disagree & 25.8 & 20.9 & 23.9 \\
Strongly Disagree & 32.0 & 25.6 & 16.0 \\
\hline
\end{tabular}

As shown above, $57.8 \%$ of the students did not agree that SAT computer programs were effective. Another $27.9 \%$ did not know if they were or not. The above also displays that $46.5 \%$ of the students did not agree that SAT preparation classes were effective, and another $22.5 \%$ did not know if they were or not. Specific SAT information taught in general classes was perceived by the greatest percentage of students (44.6\%) to be effective. Only $15.5 \%$ of the students did not know if it was or not. 
PERCEIVED EFFECTIVENESS OF IDENTIFIED

SAT PREPARATION TECHNIQUES--

TEACHERS

\begin{tabular}{lccc}
\hline & $\begin{array}{c}\text { SAT } \\
\text { Computer } \\
\text { Programs }\end{array}$ & $\begin{array}{c}\text { SAT } \\
\text { Preparation } \\
\text { Classes }\end{array}$ & $\begin{array}{c}\text { Specific SAT } \\
\text { Information } \\
\text { Taught in } \\
\text { General Classes }\end{array}$ \\
\hline Don't know & 60.3 & 29.5 & 12.5 \\
Strongly Agree & 8.9 & 21.9 & 20.8 \\
Agree & 24.9 & 43.2 & 41.0 \\
Disagree & 6.2 & 4.8 & 18.1 \\
Strong Disagree & - & .7 & 7.6 \\
\hline
\end{tabular}

As shown above, 60.38 of the teachers did not know if SAT computer programs were effective. The information above also displays that 65.18 of the teachers agreed that SAT preparation classes were effective. Specific SAT information taught in general classes was perceived by the greatest percentage of teachers $(61.8 \%)$ to be effective. only 12.58 did not know if it was or not. 


\section{PERCEIVED EFFECTIVENESS OF IDENTIFIED SAT PREPARATION TECHNIQUES-- COUNSELORS / ADMINISTRATORS}

\begin{tabular}{lccc}
\hline & $\begin{array}{c}\text { SAT } \\
\text { Computer } \\
\text { Programs }\end{array}$ & $\begin{array}{c}\text { SAT } \\
\text { Preparation } \\
\text { Classes }\end{array}$ & $\begin{array}{c}\text { Specific SAT } \\
\text { Information } \\
\text { Taught in } \\
\text { General Classes }\end{array}$ \\
\hline Don't Know & 33.3 & 29.5 & 17.9 \\
Strongly Agree & 15.4 & 21.9 & 5.1 \\
Agree & 48.7 & 43.2 & 61.5 \\
Strongly Disagree & - & .7 & 2.6 \\
\hline
\end{tabular}

As shown above, $64.1 \%$ of the counselors/administrators perceived that SAT computer programs were effective. The information above also displays that 65.18 of the counselors/administrators agreed that SAT preparation classes were effective. The greatest percentage of counselors/administrators $(66.6 \%)$ agreed that specific SAT information taught in general classes was an effective SAT preparation technique. 
Student, Teacher, Counselor/Administrator

Perceived Effectiveness of Three SAT Preparation Techniques

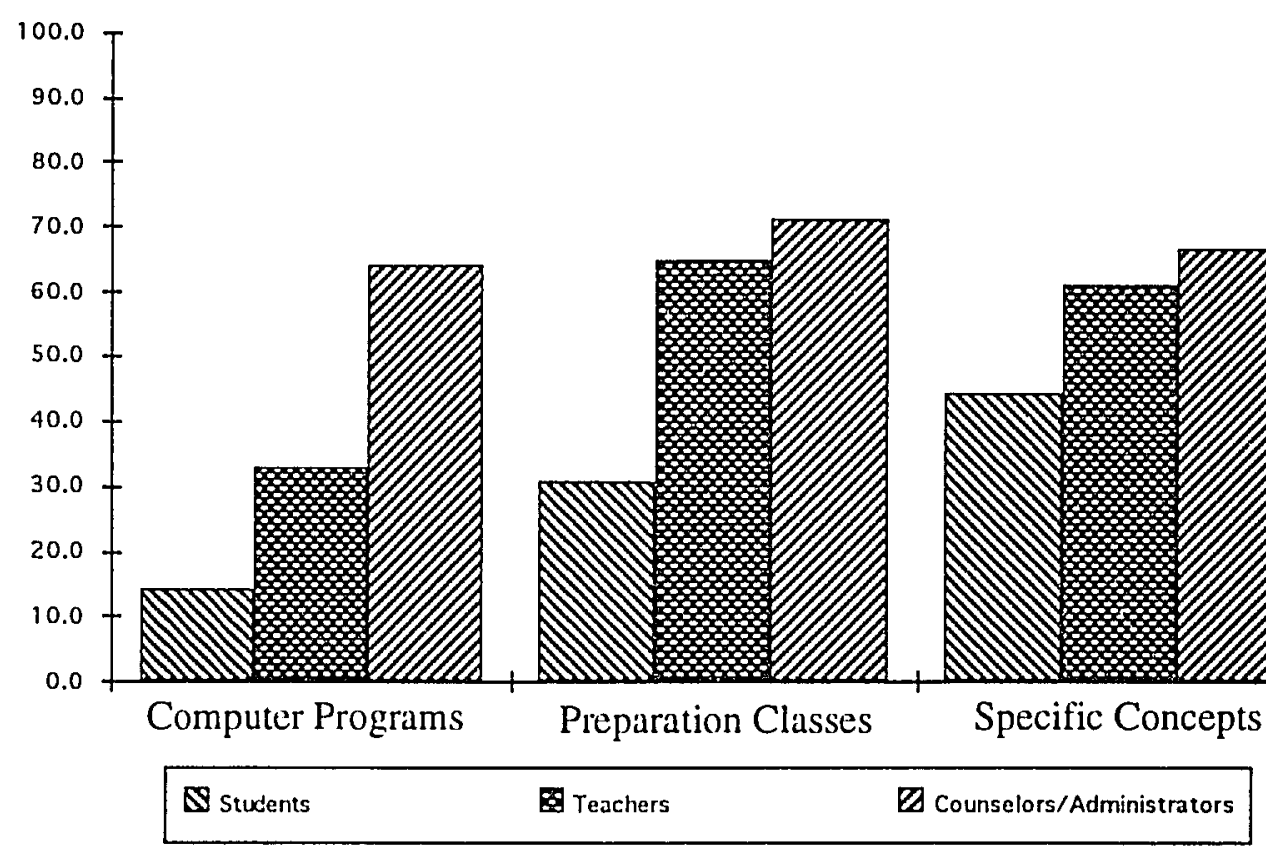

There was a significant difference in perception of effectiveness among students, teachers, and counselors/administrators about each of the three preparation techniques. 
ARE STUDENTS WHO VALUE THE SAT MORE LIKELY TO KNOW ABOUT THE THREE PREPARATION TECHNIQUES THAN

THOSE WHO DO NOT VALUE THE SAT?

\begin{tabular}{|c|c|c|}
\hline & $\begin{array}{l}\text { o Value } \\
\text { the SAT }\end{array}$ & $\begin{array}{l}\text { \& Do Not } \\
\text { Value the SAT }\end{array}$ \\
\hline $\begin{array}{l}\text { SAT Computer Programs } \\
\text { Are Available }\end{array}$ & 8.3 & 8.1 \\
\hline $\begin{array}{l}\text { SAT Preparation classes } \\
\text { Are Available }\end{array}$ & 15.9 & 12.9 \\
\hline $\begin{array}{l}\text { Teachers in My classes } \\
\text { Mention That Specific } \\
\text { Topics Will Be Present } \\
\text { on the SAT }\end{array}$ & 46.2 & 37.8 \\
\hline
\end{tabular}

